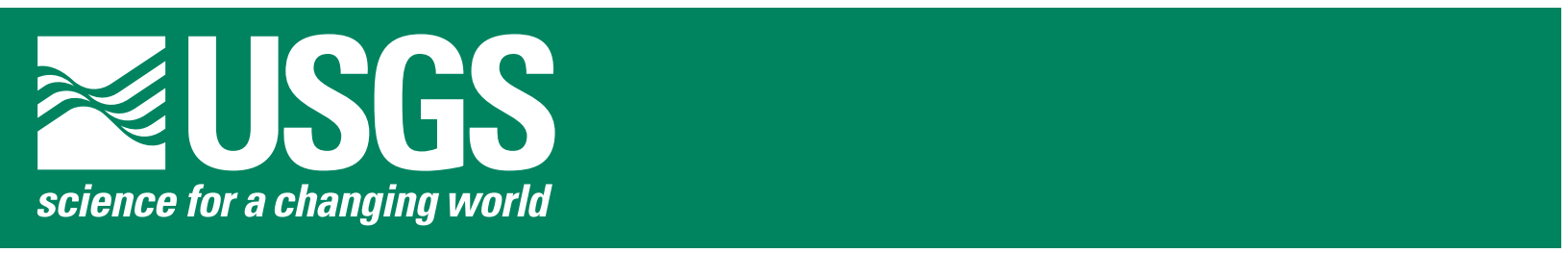

\title{
Yellowstone Plume Head: Postulated Tectonic Relations to the Vancouver Slab, Continental Boundaries, and Climate
}

by Kenneth L. Pierce, ${ }^{1}$ Lisa A. Morgan, ${ }^{2}$ and Richard W. Saltus ${ }^{2}$

Open-File Report 00-498

Online Edition

2000

This report is preliminary and has not been reviewed for conformity with U.S. Geological Survey editorial standards (or with the North American Stratigraphic Code). Any use of trade, product, or firm names is for descriptive purposes only and does not imply endorsement by the U.S. Government.

U.S. DEPARTMENT OF THE INTERIOR

U.S. GEOLOGICAL SURVEY

\footnotetext{
${ }^{1}$ Bozeman, Montana

${ }^{2}$ Denver, Colorado
} 


\begin{abstract}
We trace the Yellowstone hotspot track back to an apparent inception centered near the OregonNevada border. We and others have concluded this is the locus of a starting plume or plume head. Consideration of this plume-head model leads us to discuss the following three implications.

(1) The apparent center of the relic plume head is about $250 \mathrm{~km}$ west of the location where both the trend of the younger hotspot track and the inferred plate motions would place the hotspot at $16 \mathrm{Ma}$. A possible explanation for this discrepancy is the westward deflection of the plume up the inclined Vancouver slab. Plate tectonic reconstructions and an intermediate dip for the Vancouver slab indicate a plume head would have encountered the Vancouver slab.
\end{abstract}

(2) The postulated arrival of the plume head at the base of the lithosphere is temporally associated with eruption of the Columbia River and Oregon Plateau flood basalts at 14-17 Ma; however, these basalts were erupted several hundred kilometers north of the apparent plume center. The postulated plume center is symmetrically located near the midpoint of the 1,100-km-long Nevada-Oregon rift zone (see fig. 1). Strontium isotopic variations reflect crustal and mantle lithosphere variations along the trend of this rift zone, with the basalt area of Oregon and Washington lying west of the 0.704 line in oceanic crust, the apparent center in northern Nevada between the 0.704 and 0.706 line in intermediate crust, and the area of central and southern Nevada east of the 0.706 line in Precambrian continental crust. Geophysical modeling is consistent with a dense crust north of the Nevada-Oregon border and an asthenospheric low-density body that extends several hundred kilometers south and north of the Nevada-Oregon boundary. A reconstruction of the initial contact of the plume head with the lithosphere suggests relatively thin lithosphere at $17 \mathrm{Ma}$ beneath Oregon and Washington, which would favor the spreading of the plume northward in this direction, more decompression melting in this "thinspot" area, and the eruption of basalt through dense, oceanic lithosphere. Thus, preferential extrusion of flood basalts north of the plume center may be the result of differences in the pre-plume lithosphere, and not the location of the center of the plume head.

(3) A plume head rising into the base of the lithosphere is expected to produce uplift, which we estimate to be on the order of $1 \mathrm{~km}$ with a north-south dimension of $1,000 \mathrm{~km}$. This plume-head uplift, followed by subsidence, is consistent with Cenozoic paleobotanical altitude estimates. Other climatic indicators show major aridity about $15 \mathrm{Ma}$ in areas in the inferred precipitation shadow east of the inferred uplift. Indicators of climate about $7 \mathrm{Ma}$ are compatible with an eastward migration of uplift to a site between the plume-head area and the present Yellowstone crescent of high terrain. The warm Neogene "climate optimum" correlates with 14-17-Ma flood basalt and rhyolite volcanism. The continued effects of Yellowstone plume-head uplift and ensuing plume tail uplift, if real, could provide regional uplift that is geophysically plausible. Climatic modeling has shown that uplift of the age and latitude of the postulated Yellowstone plume-head uplift, if allied with Himalayan and perhaps other uplifts could result in the late Cenozoic cooling leading to the Pliocene-Pleistocene ice ages (Kutzbach and others, 1989; Ruddiman and others, 1989, 1997).

Thus, the postulated Yellowstone plume head could have played an important role in the late Cenozoic geologic history of the northern, interior part of the U.S. Cordillera. Future studies of the kind briefly discussed here should provide a better evaluation of the Yellowstone plume head concept.

\title{
INTRODUCTION
}

A common explanation of hotspot tracks, such as the one responsible for the Hawaiian Islands, is that they are generated by the interaction of a relatively fixed deep thermal plume with a moving lithospheric plate. Richards and others (1989) suggested that mantle plumes initiate as larger plume heads that produce associated flood basalts and then evolve into narrower plume tails associated with later, smaller volume volcanism. Thermal mantle plumes are controversial in part because they cannot be directly 
investigated; the narrow plume tails are too small in cross section to be imaged seismically. Mantle plumes are thought by many, however, to explain an important and still poorly resolved piece of the generally accepted plate-tectonic model. A starting plume head rises slowly from deep in the mantle and is fed from below by a much thinner tail or chimney in which heated material is rising through the "tail pipe" an order of magnitude faster than the plume head rises. Thus, as the plume head rises, it inflates to diameters of hundreds or perhaps more than a thousand kilometers before it slowly impacts the base of the lithosphere. Upon rising the last $150 \mathrm{~km}$ or so, decompression melting in the plume head results in the eruption of flood basalts. In his presidential address to the Geological Society of America, George Thompson (1998) argued for the importance of deep mantle plumes in general and the Yellowstone plume head and tail in particular, concluding that The paradigm of deep mantle plumes, like plate tectonics or asteroid impacts, supplies a wonderful unifying concept for geoscientists and for communicating our science to the world at large.

Plume heads produce a large area of uplift that starts before their actual arrival at the base of the lithosphere (Hill and others, 1992). Hotspot swells with heights of 1-2 km and diameters of 800-1,200 km (Crough, 1978) are associated with current hotspot positions commonly inferred to be plume tails. The partial melting of upwelling hot mantle produces two materials that are both lighter than the original mantle (density about $3.3 \mathrm{~g} / \mathrm{cc}$ ): basalt melt (density about $3.0 \mathrm{~g} / \mathrm{cc}$ ) that rises upward and restite residuum (density perhaps about $3.0 \mathrm{~g} / \mathrm{cc}$ ) that stays in the mantle (Morgan and others, 1995).

Despite their apparent unifying appeal, many dispute the mantle plume idea. For example, in the Pacific plate near the Hawaiian, Society and Marquesas hotspots, Katzman and others (1998) determined that upper mantle velocities were high and not low as predicted by traditional hotspot thermal models. They suggest Richter-type convective rolls above the $660-\mathrm{km}$ discontinuity and oriented parallel to plate velocity rather than a deep thermal plume. Don Anderson (1998 and references therein) argues against the mantle-plume explanation of hot spots and particularly the deep-seated mantle plume idea and presents alternative explanations to plume arguments.

In contrast, the recent book "The Earth's Mantle" contains many chapters by different authors support the concept of deep mantle plumes, and the concept of starting plumes or plume heads. Griffiths and Turner (1998) present argument for the concept of a starting plume head, fed by a plume tail. Davies (1998) describes mantle convection with descending slabs and rising plumes. Based on chemical considerations, Campbell (1998) argues for a deep plume source for ocean island basalts. Based on seismological and experimental studies, Jackson and Rigden (1998) argue that the mantle is grossly uniform in chemical composition throughout and that phase transformations provide an adequate explanation for the seismically observed radial structure. In another book, Garnero and others (1998), recognize an ultralow velocity zone (ULVZ) that may represent partial melting at the core-mantle boundary. Correlation of this ULVZ with surface hotspot distribution and anti-correlation with descended slabs suggests whole mantle convection may intersect just above the core-mantle boundary.

As a test of the viability of the Yellowstone plume hypothesis, we were led into the problem of addressing the initial stages of the Yellowstone plume head by tracking the Yellowstone hotspot back to the west from its present location at the Yellowstone Plateau (Pierce and Morgan, 1990, 1992; fig. 1, hotspot track; Anders and others, 1989; Rodgers and others, 1990; Malde, 1991; Smith and Braile, 1993). The hotspot track is associated with a northeastward progression of rhyolitic volcanic fields, faulting, and uplift. The segment containing the 10-Ma-and-younger rhyolitic volcanic progression is linear in both rate and trend and is reflected in the topographic depression of the eastern Snake River Plain (SRP). In contrast, the segment containing the 10-Ma-and-older rhyolitic progression includes two calderas active about 10 Ma but spaced 100-200 km apart (Morgan and others, 1997). The progression associated with rhyolitic volcanism becomes increasingly diffuse to the southwest. The earliest stages of this Yellowstone style volcanism can be projected back in space and time along this trend to the McDermitt caldera com- 
plex along the Nevada-Oregon boundary about 16 Ma (Malde, 1991; Thompson and Gibson, 1991; Pierce and Morgan, 1992) and to the northern part of the northern Nevada rift (Zoback and Thompson, 1978). As pointed out by Pierce and Morgan (1992), the 10-Ma and younger trend has an orientation of N. $54^{\circ}$ E. and an apparent rate of 2.9 centimeters/yr while the 10-Ma and older trend has an orientation of $\mathrm{N} .75^{\circ} \mathrm{E}$. and an apparent rate of 7.0 centimeters/yr. These differences in apparent orientation and rate compound the problem of clearly identifying the initial hotspot starting location.

Based largely, however, on the track of the Yellowstone hotspot and its Columbia River-Oregon Plateau flood basalt association, the initial stages of the Yellowstone starting plume (head) have been inferred to begin at about 17 Ma beneath the northern Basin and Range (Zoback and Thompson, 1978; Hooper, 1990; Duncan and Richards, 1991; Thompson and Gibson, 1991; Draper, 1991; Zoback and others, 1994; Camp, 1995; Parsons, 1995). The large sublithospheric density deficit required to support high topography at this location is interpreted by Parsons and others (1994) and Saltus and Thompson (1995) to be the remnants of the Yellowstone plume head.

If we assume the nascent Yellowstone starting plume intercepted the lithosphere centered near the Nevada-Oregon border about $17 \mathrm{Ma}$, then the following possible relationships need to be examined and have implications on understanding the region: (1) The rising plume head may have interacted with and been diverted westward by the inclined Vancouver slab of oceanic lithosphere. This interaction may explain the anomalously high apparent volcanic migration "rate" from 16 to $10 \mathrm{Ma}$ which does not correspond with a known change in rate of the North American Plate. (2) Differences in the character of the pre-plume lithosphere along a NNW-SSE 1,000-km-long trend centered near McDermitt may account for the different geologic features observed, particularly the 14.5- to 17.5-Ma major pulse of Columbia River-Oregon Plateau flood basalt eruptions north of the center of the plume head (assumed to be near the McDermitt caldera complex) and the dike injection along the 500-kilometer-long northern Nevada rift and associated 14- to 17-Ma basaltic and silicic volcanism near and south of this center. (3) Significant topographic domal uplift above the plume head may have had great impact on past global and northwest U.S. climates and may explain regional changes in topography since the middle Miocene. If geologic observations support these three relations, this may provide support to the plume-head hypothesis. In addition to the three relations described above, the current high regional heat flow (Blackwell, 1989; Lachenbruch and Sass, 1978) and ongoing extension of the Basin and Range region of the North American plate may also relate to the stagnant Yellowstone plume head.

\section{WESTWARD DISPLACEMENT OF PLUME HEAD BY INCLINED VANCOUVER SLAB}

Zoback and Thompson (1978) first suggested that the Yellowstone hotspot surfaced in northern Nevada about 16 Ma. Malde (1991) noted that the oldest set of calderas along the Yellowstone hot-spot track erupted the 16.1-Ma rhyolites of the McDermitt field (Rytuba and McKee, 1984, fig. 1). Several others have also postulated the McDermitt area near the Nevada-Oregon border (fig. 1) to be the approximate location of a large starting-plume (Yellowstone plume head, Thompson and Gibson, 1991; Draper, 1991; Pierce and Morgan, 1992; Parsons and others, 1994; Zoback and others, 1994; Camp, 1995).

Placing the starting position in the McDermitt area raises some problems, as noted but not explained by Pierce and Morgan (1992). The apparent rate of hotspot migration from 16 to $10 \mathrm{Ma}$ is 7 centimeters/ yr, more than twice the 10-Ma to present 2.9 centimeters/yr apparent rate (Pierce and Morgan, 1992). On the basis of intervals of very high fault offset, Anders and others (1994) determined a plate migration rate, accounting for extension, of $22 \mathrm{~km} / \mathrm{m} . \mathrm{y} .(\mathrm{km} / \mathrm{m} . \mathrm{y} .=\mathrm{mm} / \mathrm{yr})$, quite compatible with a global hotspot (but excluding Yellowstone) plate tectonic rate of $2.2 \pm 0.8 \mathrm{~km} / \mathrm{m}$.y. (Alice Gripps, written commun., 1991, in Pierce and Morgan, 1992).

Projection of the trend of the 2- to 10-Ma hotspot track back to 16 Ma yields a location near the 


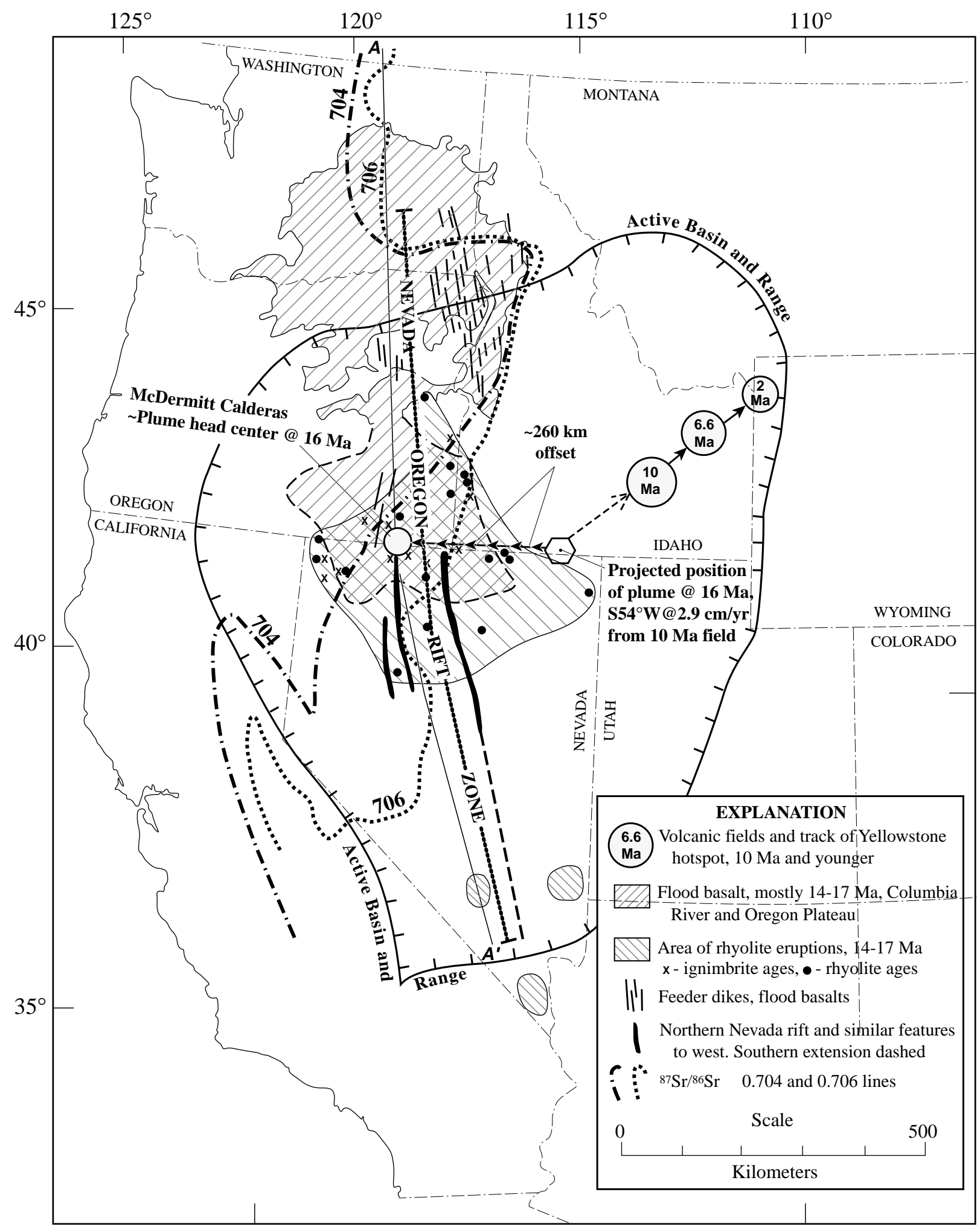

Figure 1. Map of western United States showing the track of the Yellowstone hotspot (after Pierce and Morgan, 1992, fig. 23). The 10- to-2-Ma track is compatible with plate motion, whereas the 10- to-16-Ma track has apparent rates three times faster than predicted. Projecting back from $10 \mathrm{Ma}$, we infer the plume was located at the site of the hexagon. As shown by the arrowed line, the geologic location of the inferred plume head was about 260 $\mathrm{km}$ further west at about the McDermitt caldera. Assuming the Vancouver slab was in the subsurface (figs. 2 and 3), buoyant rise up the slab may have deflected the plume head westward the $260 \mathrm{~km}$ shown by the arrowed line. Strontium lines after Reed (1993) with modifications in Washington from Robert Fleck (written commun., 1998) and southeastern Idaho from Leeman and others (1992). Transect A-A' is portrayed in Figure 5. 
Idaho-Utah border about $250 \mathrm{~km}$ east of the apparent starting plume centered near McDermitt. West of the 10-Ma Picabo volcanic field, successively older fields have a very crude trend that ends up at McDermitt, but this direction of hotspot migration from 16 to $10 \mathrm{Ma}$ is N. $75^{\circ} \mathrm{E}$., about $20^{\circ}$ different from the direction of N. $54^{\circ}$ E. from 10 to 2 Ma.

We have not accounted for the amount of extension (Rodgers and others, 1990) after 16 Ma over the present distance of $430 \mathrm{~km}$ between the McDermitt area and the 10-Ma Picabo volcanic field, other than to assume the observed post-10-Ma rate of $29 \mathrm{~km} / \mathrm{m} . \mathrm{y}$. is the vector sum of the plate rate and the extension rate. If extension has been constant after $16 \mathrm{Ma}$, this is only about $25 \%$ of the total calculated rate of "migration" based on Anders (1994) estimation of $22 \mathrm{~km} / \mathrm{m}$.y. for plate motion combined with $7 \mathrm{~km} / \mathrm{m}$.y. of tectonic extension to result in a combined rate of $29 \mathrm{~km} / \mathrm{m}$.y. One observation that suggests extension has been minor is the smooth, relatively unfaulted topography between McDermitt and the central SRP as shown on the shaded relief map of the U.S. (Thelin and Pike, 1991). This broad plateau is formed largely of 10- to 16-Ma volcanic strata (Luedke and Smith, 1981, 1982, 1983) suggesting little faulting since that time.

Other evidence based on fission track studies in the eastern Basin and Range province, however, suggests major extension occurred between 20 and $15 \mathrm{Ma}$ (Elizabeth Miller, written commun., 1999). Local extension east of McDermitt is indicated by opening of the Western Snake River Plain (a few 10's of $\mathrm{km}$ ), and by opening of the Raft Valley by the eastward sliding of the Black Pine and Sublette Ranges off the Albion Range (Covington, 1983, also shown in Pierce and Morgan, 1992, fig. 11). If extension east of McDermitt is as large as $260 \mathrm{~km}$, this could then explain the $260 \mathrm{~km}$ westward offset of the 16-Maplume location (fig. 1) in the last $16 \mathrm{Ma}$, and following hypothesis of westward deflection by the Vancouver slab would not be needed.

\section{RECONCILIATION BASED ON WESTWARD DEFLECTION BY THE VANCOUVER SLAB}

We suggest here that the apparent discrepancy between both rate and azimuth of hotspot migration can be explained by the westward displacement of the plume head when it rose up into the east-dipping Vancouver (or Juan de Fuca) slab (figs. 2, 3). Geist and Richards (1993) suggested that the Yellowstone plume intercepted the Vancouver slab before $17 \mathrm{Ma}$, but they argued that the downward and strong northeast motion of the Vancouver plate trapped the plume for some time and carried it northward to near the common borders of Washington, Oregon, and Idaho where it eventually broke through the slab and produced the Columbia River flood basalts (fig. 1). We modify their idea of interaction with the Vancouver slab by suggesting that buoyant gravitational forces would be more effective than tractive forces and that the plume would buoyantly rise up along the lower surface of the inclined slab, rather than being dragged northward and held down by the northeastward-moving and descending Vancouver slab. For a plume beneath a horizontal plate, tractive forces, where not opposed to gravity, do appear significant. We also propose a starting plume (or plume head) interacting with the Vancouver slab rather than an already existing plume tail (or chimney) that previously had been located beneath the Pacific Ocean as proposed by others (Geist and Richards, 1993; Duncan, 1982). The possible interaction of the Vancouver slab with the Yellowstone plume has been proposed by several others (Leeman, 1982; Duncan, 1982; Draper, 1991; Hill and others, 1992; and Hooper and Hawksworth, 1993).

To reconstruct the interaction of the Vancouver slab with the Yellowstone hotspot, we have used the plate tectonic reconstructions of Severinghaus and Atwater (1990; fig. 2). We have projected the track of the Yellowstone hotspot back in time on the basis of its 2- to $10-\mathrm{Ma}$ rate of $2.9 \mathrm{~cm} / \mathrm{yr}$ at S. $54^{\circ} \mathrm{W}$. (includes both plate rate and extension rate, Pierce and Morgan, 1992), using reconstructions for 30, 20, 10, $0 \mathrm{Ma}$ (Severinghaus and Atwater, 1990). Projecting the direction and rate from 2-10 Ma back to $16 \mathrm{Ma}$ is warranted for the "paleomap" models of global plate motion (Malcolm Ross, written commun., 1998, 
based on paleomap programs). Such models show the North American Plate having no more than a 4degree change in direction and 3 percent variation in rate over the last $20 \mathrm{Ma}$. However, a 12-degree change in direction and a 17 percent increase in rate are indicated about 20-21 Ma, which is before the volcanism we associate with the Yellowstone hotspot.

Figure 3 is a time sequence of cross sections incorporating the above rate with plume rise models and plate tectonic reconstructions. For the plume head, we have used a rise rate of $0.1 \mathrm{~m} / \mathrm{yr}(100 \mathrm{~km} / \mathrm{m} . \mathrm{y}$.) suggested by Richards and others (1989) going back in time (and downward) from its interception with the North American plate (lithosphere) about $17 \mathrm{Ma}$ ago. We estimate the volume of the plume head in the upper mantle to be roughly $400 \mathrm{~km}^{3}$ based on: (1) the volumes erupted from the Columbia River-Oregon Plateau flood basalts (Hooper, 1997; Carlson and Hart, 1988), assuming 5-30 percent of partial melting (202-368 km³ Coffin and Eldholm, 1994), plus (2) the linear extent of erupted and injected material along the 500-km Nevada rift zone (Zoback and others, 1994); and (3) the residual mass deficit shown by Parsons and others (1994) for the northern Nevada area that is comparable to the expected deficit produced by a small plume head with a diameter of about $400 \mathrm{~km}$ and 100-300 degrees $\mathrm{C}$ hotter than the surrounding asthenosphere (Hill and others, 1992). We assume the chimney (tail) of the Yellowstone plume has been held fixed over time (fig. 3) and that the North American plate has migrated at $22 \mathrm{~km} / \mathrm{m} . \mathrm{y}$. and the hotspot has migrated at $29 \mathrm{~km} / \mathrm{m}$.y. (plate motion plus extension). As already noted, we assume the heated material in the tail is rising at about $1.0 \mathrm{~m} / \mathrm{yr}$, which is an order of magnitude faster than the rate of the ascending plume head $(0.1 \mathrm{~m} / \mathrm{yr}$; or $100 \mathrm{~km} / \mathrm{m} . \mathrm{y}$.). Thus, ascending material in the plume tail would contribute to inflation of the more slowly rising plume head.

The inclination of the Vancouver slab is difficult to constrain. About $50 \mathrm{Ma}$, it is thought to have been flat (see discussion in Atwater, 1989, p. 46-49). At present the dip as far inland as the CascadesColumbia Plateau boundary is 12 degrees (Parsons and others, 1998). Further inland and with more difficult techniques, Rasmussen and Humphreys (1988) estimate a dip of about 65 degrees near the Washington-Oregon boundary, and VanDecar (1991) estimate about 60 degrees beneath Washington. Seismic imaging by van der Lee and Nolet (1997) shows remnants of the Vancouver slab at $500 \mathrm{~km}$ beneath the area near Salt Lake City, suggesting a time-averaged dip of about 30 degrees; they suggest a flat slab extending $1,000 \mathrm{~km}$ inland at $50 \mathrm{Ma}$, and at about 30 degrees dip extending more than $50 \mathrm{~km}$ inland at $30 \mathrm{Ma}$. Geist and Richards (1993) draw about a 35 degrees slab dip at $20 \mathrm{Ma}$. We have drawn a dip of about 40 degrees at $30 \mathrm{Ma}$ that steepens to 45 degrees at $16 \mathrm{Ma}$ and 50 degrees at present.

By about $20 \mathrm{Ma}$, the starting plume intercepted the Vancouver slab (fig. 3). If gravitational buoyancy dominates over tractive forces, the buoyant plume head would be deflected to the west by the west-rising lower surface of the Vancouver slab. We suggest the tractive force that the Vancouver slab could exert on the relatively low viscosity plume head, particularly by dragging the plume head down, would be minor compared to the buoyant rise of an expanding starting plume. Put more simply, how would the hot, low viscosity plume head stick to the steeply inclined slab? Also, consideration must be given to the slope angle of the descending slab. If the slope is as steep as 60 degrees, as inferred by Rasmussen and Humphreys (1988), traction would have even less of an effect on the ascending plume and thus would not block it.

Buoyant rise directly up the slab would displace the plume head to $\mathrm{S} .70^{\circ} \mathrm{W}$. That the deflection appears to be essentially to the west may reflect a small component of northward drag due to the northeasterly movement of the Vancouver slab relative to the North American plate.

With this westward offset by the Vancouver slab, the apparent rate of migration of volcanism between 16 and $10 \mathrm{Ma}$ is an additive combination of the projected plate motion plus extension of $29 \mathrm{~km} /$ m.y. for 6 m.y. equaling $175 \mathrm{~km}$ plus the $250 \mathrm{~km}$ net offset by the Vancouver plate. This results in an apparent migration of approximately $420 \mathrm{~km}$ in $6 \mathrm{~m} . \mathrm{y}$., solved so as to yield the apparent migration rate of $70 \mathrm{~km} / \mathrm{m} . \mathrm{y}$. 


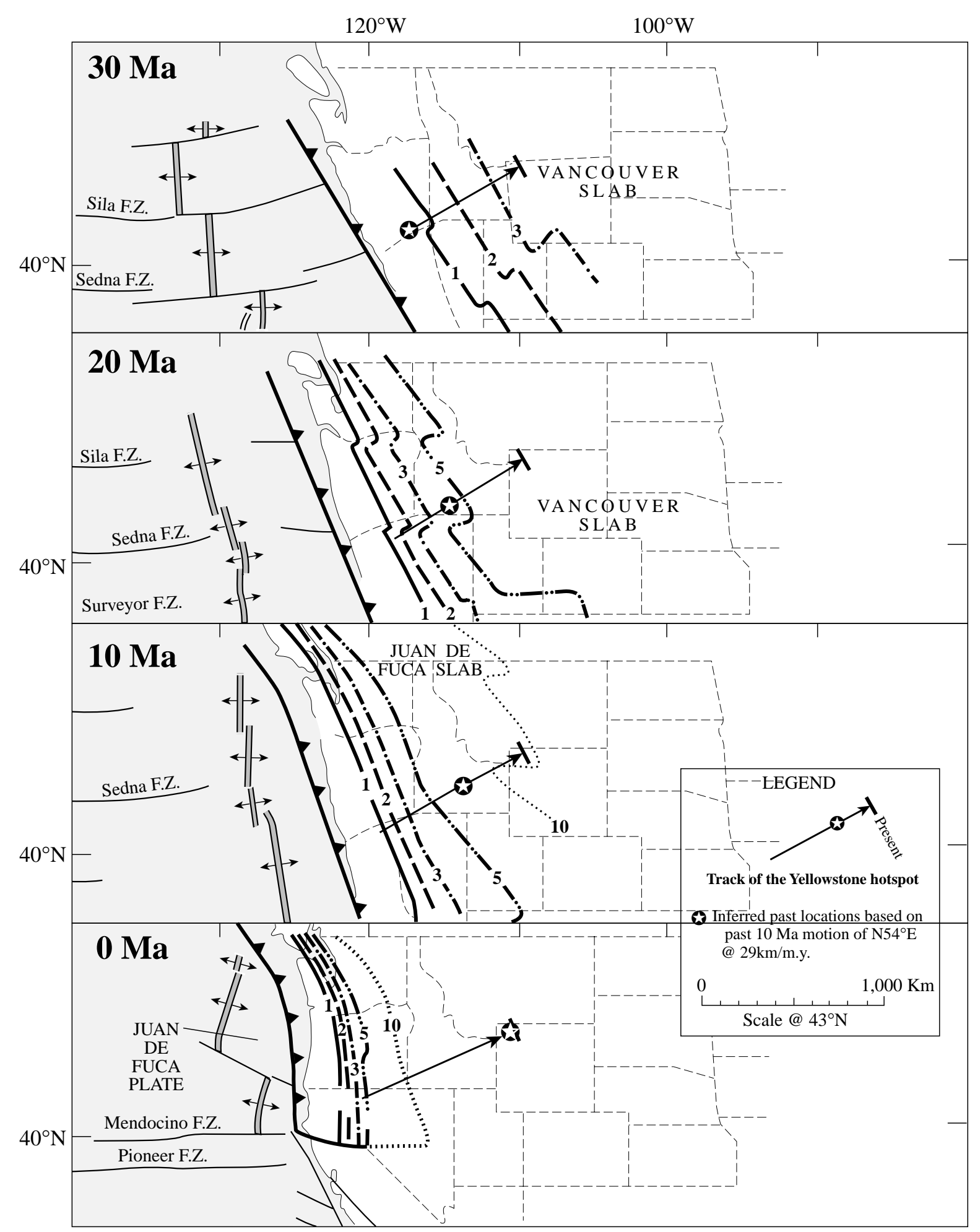

Figure 2. Location of the Yellowstone plume relative to the North American Plate and the Vancouver slab (or Juan de Fuca slab; from Severinghaus and Atwater, 1990). The plume is assumed to be fixed in the mantle and now 50-km northeast of the 2.0-Ma caldera that started the Yellowstone Plateau volcanic field. Hotspot migration of $29 \mathrm{~km} / \mathrm{m}$.y. from 2 to $10 \mathrm{Ma}$ is plotted as a circled star on the line of section. This rate of $29 \mathrm{~km} / \mathrm{m}$.y. is close to the plate motion rate of $22 \pm 8 \mathrm{~km} / \mathrm{m}$.y. and includes tectonic extension that probably accounts for the apparent difference of $7 \mathrm{~km} / \mathrm{m}$.y. Cross sections are drawn to go through the McDermitt caldera and are nearly parallel to plate motion and to the inclination of the Vancouver slab. The reconstruction of Severinghaus and Atwater (1990) accounts for deformation, and the numbers on the Vancouver slab indicate the thermal state of the slab with 1 meaning solid enough to have earthquakes and 10 meaning nearly the same as the surrounding mantle. 

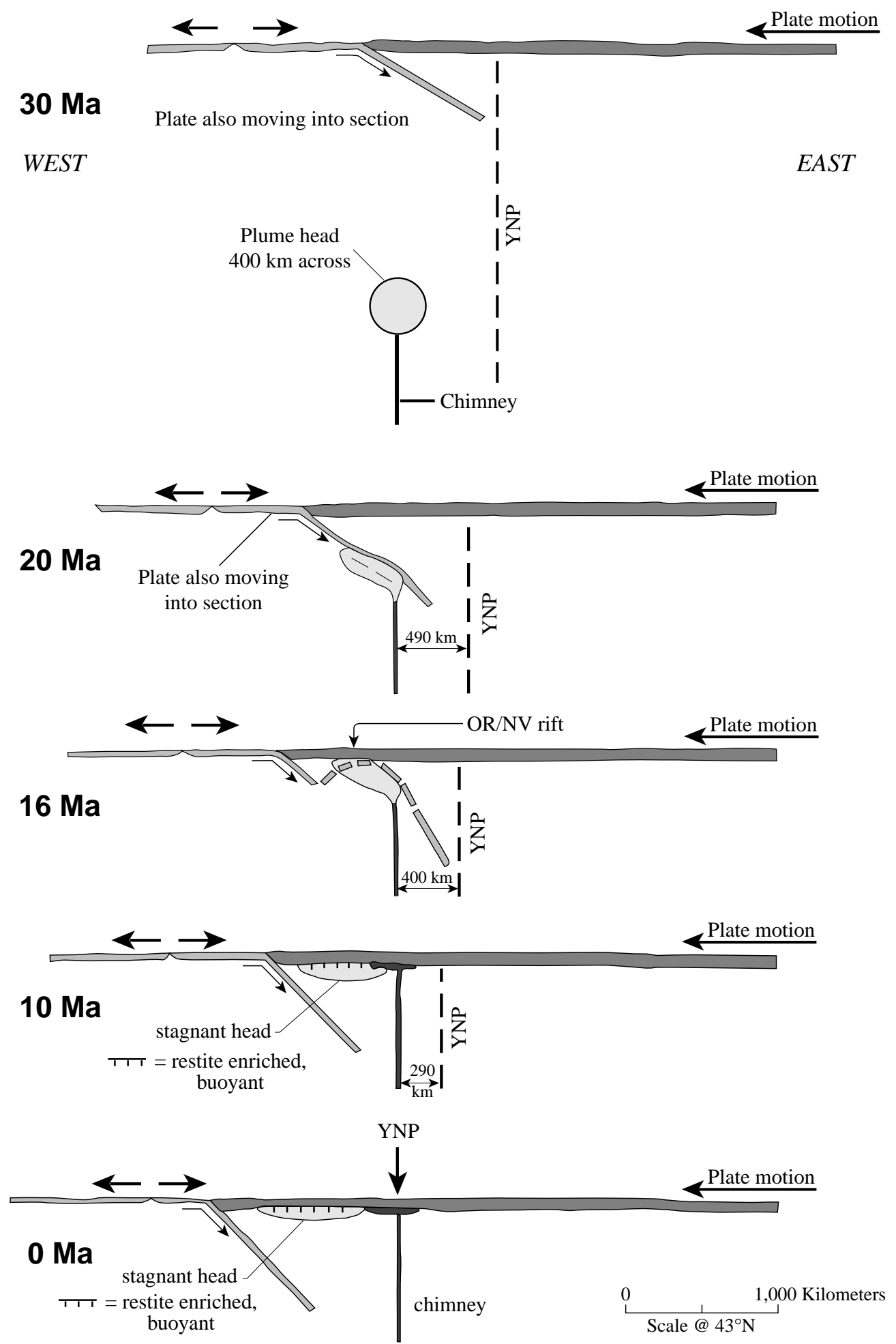

Figure 3. Postulated westward deflection of the Yellowstone plume head by buoyant rise up the inclined Vancouver slab. Time sequence from 30 Ma (top) to present (bottom) with position of plume held fixed in the mantle. At $20 \mathrm{Ma}$, the plume head has intersected the inclined Vancouver slab and is being displaced westward, and by $16 \mathrm{Ma}$ the plume center is beneath McDermitt (along the OR/NV rift), about $260 \mathrm{~km}$ west of its feeding plume tail. As the plume flattens, the area of the plume in this cross section diminishes to about half because of spreading in the third dimension. The inclination of the Vancouver slab is shown to increase from 30 Ma to present (see text under heading "Reconciliation Based..."). Numbers on slab (1, 3, 5, and 10) are the thermal state of slab from Severinghaus and Atwater (1990); see also Figure 2. This cartoon does not account for interaction with the 660- and 410-km discontinuities. 


\section{OTHER PROPOSED LOCATIONS OF THE YELLOWSTONE HOTSPOT}

A number of proposals about the location of the Yellowstone plume at different times have been advanced (fig. 4). Geist and Richards (1993) suggest the Yellowstone plume was trapped for some time and carried northward by the Vancouver slab to a position beneath the main extrusion area of the Columbia River basalts. Our idea builds on the Vancouver slab interaction suggested by Geist and Richards (1993). We propose that buoyant forces dominated tractive ones and that the plume head was centered near the Nevada-Oregon border.

In the next section and earlier (Pierce and Morgan, 1992), we argue that the nascent Yellowstone plume intercepted the lithosphere near the McDermitt caldera area and that the apparent asymmetry related to the rhyolitic track of the Yellowstone hotspot with respect to the location of the Columbia River-Oregon Plateau flood basalts is due to changes in pre-plume lithosphere thickness and crustal composition. We argue herein and in our prior paper (Pierce and Morgan, 1992) that the asymmetry is merely apparent. In fact, the 1,100-km-long Nevada-Oregon rift can be considered an equal, but overlooked, component to the early stages of the plume head intercepting the base of the lithosphere, as are the voluminous flood basalt eruptions to the north. Both components are symmetrical to the McDermitt area. Specifically, the Columbia River-Oregon Plateau basalts, located primarily north of the McDermitt center and north and off the trend of the hotspot track, are the product of a thinner, more mafic, younger accreted crust (Hooper, 1997) where the flood basalts surfaced while the northern Nevada rift developed in thicker, Proterozoic to Paleozoic, mafic to transitional accreted crust. From 14 to $16 \mathrm{Ma}$ in northern Nevada and adjacent parts of Oregon and Idaho, there was widespread silicic volcanism, although the locations of the calderas have not been well established (fig. 1; Luedke and Smith, 1981, 1982. 1983).

Oppliger and others (1997) suggest that the 34-to 43-Ma "Carlin" gold mineralization at Carlin, Nevada, is associated with an "incubation period" of an early Yellowstone plume. They cite the rich abundance of gold and related siderophile elements in the Carlin deposits as being plume related and note that these enriched elements are thought to be derived from the core-mantle boundary where many think thermal plumes originate. We suggest, however, that having the Yellowstone plume beneath northern Nevada at 34-43 Ma is difficult to reconcile considering the rate and direction of motion of the North American plate (fig. 4) and the current location of the Yellowstone plume. Assuming a rate of $29 \mathrm{~km} / \mathrm{m} . \mathrm{y}$. in a direction of S. $55^{\circ} \mathrm{W}$. from Yellowstone places a 40-Ma plume somewhere near Sacramento, California, quite distant from Carlin, Nevada. The lack of volcanic deposits or related rifts that may have recorded the passage of a thermal plume in a time-transgressive pattern to the southwest from McDermitt is striking. Furthermore, given our conclusion that the Yellowstone plume head intercepted the lithosphere at about 17 Ma near McDermitt, we cannot reconcile the proposal by Oppliger and others (1997) that the plume head was southeast of McDermitt and only $380 \mathrm{~km}$ from the $10 \mathrm{Ma}$ position of the hotspot. Such a location would yield an anomalously slow plate tectonic migration rate of $11 \mathrm{~km} / \mathrm{m}$.y.; this rate would also include any basin and range extension (fig. 4).

In a related paper by the same authors, Murphy and others (1998) suggest that before 40 Ma, the Yellowstone plume was further west (fig. 4) and the plume track had been subducted in advance of the time when the actual plume went under the North American plate about $55 \mathrm{Ma}$. Thus, the plume track and

associated swell more than $1,500 \mathrm{~km}$ long was subducted prior to $55 \mathrm{Ma}$. Their paper stresses the idea that subduction of a plume track swell could add buoyancy to the subducted slab and affect the Cretaceousearly Tertiary orogeny. Their hotspot track differs in rate and orientation from that determined by the hotspot track volcanism (Pierce and Morgan, 1992), by hotspot faulting (Anders 1994), and plate motion (Alice Gripps in Pierce and Morgan, 1992, p. 6).

Bob Duncan (1982) proposed "a captured island chain in the Coast Range of Oregon and Washington" and attributes this to the Yellowstone hotspot (fig. 4). He suggested that the plume was shielded from surfacing between about $17 \mathrm{Ma}$ and perhaps $30 \mathrm{Ma}$ and inferred that the plume was trapped during this 
interval beneath the Vancouver slab. More recently, part of this "captured island" terrain, termed Siletzia and dated at 51-55 Ma, has also been ascribed to a Yellowstone hotspot origin by Pyle and others (1997). If the hotspot existed before $17 \mathrm{Ma}$ and was active offshore between 50 and $60 \mathrm{Ma}$ (Duncan, 1982; Pyle and others, 1997), yet was shielded from surfacing between 17 and perhaps $25 \mathrm{Ma}$ by the sinking Vancouver slab, we would expect to see some surface manifestation of this plume west of McDermitt between 25 and $50 \mathrm{Ma}$. Furthermore, if the plume existed before to $17 \mathrm{Ma}$, why does the Nevada-Oregon rift (Pierce and Morgan, 1992; Zoback and others, 1994; Parsons and others, 1994) appear to represent a 17-Ma event extending about $500 \mathrm{~km}$ both north and south of the Oregon-Nevada border centered in the McDermitt area and overlain by rhyolitic hotspot track volcanic rocks at McDermitt? How do these models (Duncan, 1982; Pyle and others, 1997) account for such a change in magnitude of processes going from relatively small volcanic events in the late Eocene in areas well away from the current trend of the hotspot track to an approximately 40-Ma period of quiescence and a sudden large event at $17 \mathrm{Ma}$ ?

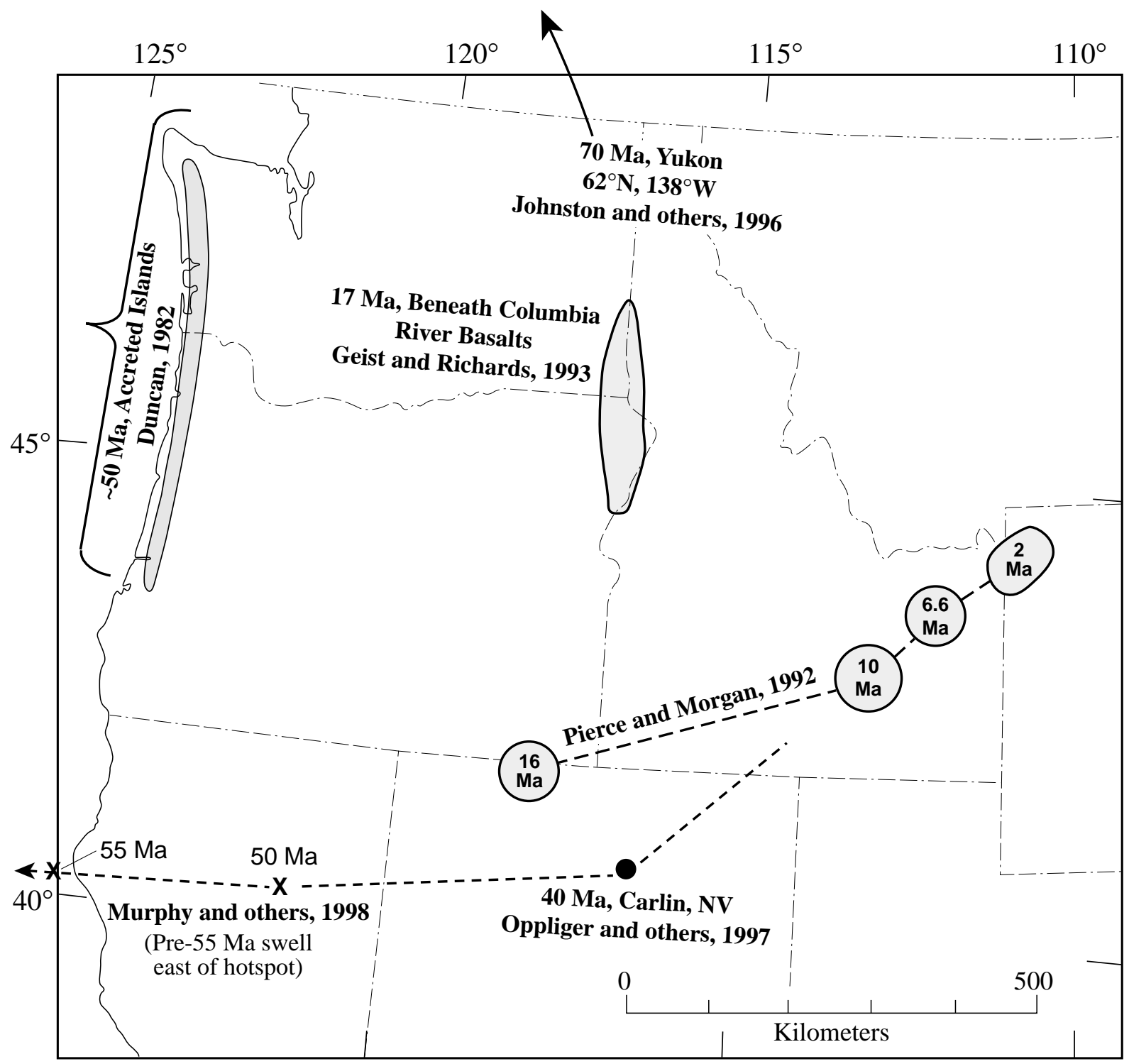

Figure 4. Some positions for the Yellowstone hotspot at different times as postulated by others and by us. The location between 50 and 17 Ma presents a problem that is avoided if the Yellowstone plume starts at $17 \mathrm{Ma}$. 
We also suggest that given our understanding of plate motions and rates during this period, it is difficult to reconcile a Yellowstone plume off the coast of the Oregon-Washington border considering its present location under the Yellowstone Plateau and its track over the past 16 m.y. which points towards Sacramento and the Great Valley of California.

A late Cretaceous location of the Yellowstone hotspot in the Yukon (fig. 4) was proposed by Johnston and others (1996). This idea depends on the 50-Ma location now on the Washington-Oregon coast, and has the same problems as discussed above.

In conclusion, we concur with Draper (1991) that no connection exists between the 0- to 17-Ma Yellowstone plume and the various models for an inferred "Yellowstone" plume 50-60 Ma off the coast of Oregon and Washington (Duncan, 1982; Pyle and others, 1997). Furthermore, westward displacement of the Yellowstone plume head by the inclined Vancouver slab as predicted from plate tectonic and plume histories seems physically plausible and explains the problem of an apparent increase in plate motion (plus extension) by more than 250 percent (from $7 \mathrm{~cm} / \mathrm{yr}$ between 10 and $16 \mathrm{Ma}$ to $2.9 \mathrm{~cm} / \mathrm{yr}$ after 10 Ma).

One possible test of the interrelation of the Yellowstone plume head with the Vancouver slab might be to look for the effects of the slab and associated subducted sediments in the chemistry of the Washington and Oregon basalts. Takahahshi and others (1998) suggest that the Grande Ronde units of the Columbia River flood basalt result from the melting of a plume head containing very old oceanic crust (Precambrian?). The arc-like geochemical signature of these basalts (high $\mathrm{Ba} / \mathrm{La}$ ratios; Hooper and Hawkesworth, 1993) leads Hooper (1997) and Shervais and others (1997) to suggest the entrainment of a subduction component into the plume head that is consistent with our proposed interaction with the Vancouver slab.

\section{THE YELLOWSTONE STARTING PLUME: TRANSECT ALONG THE NEVADA-OREGON RIFT ZONE}

The apparent asymmetry associated with the Yellowstone starting plume at 14-17 Ma can be explained by changes in the thickness and composition of the lithosphere along a north-south axis parallel to the Nevada-Oregon rift zone (figs. 1 and 5). We place the initial plume head center at the McDermitt caldera complex along the Nevada-Oregon border (fig. 1). The Columbia River-Oregon Plateau flood basalts extend for hundreds of kilometers to the north of, and give a lop-sided appearance to, the track of the Yellowstone hotspot, although we emphasize that this plume-head center is at about the midpoint of the Nevada-Oregon rift zone. Nonetheless, the location of these flood basalts with respect to the inferred initial location of the starting plume requires explanation. Geist and Richards (1993) explained this northward location of the Columbia River flood basalts by a northward diversion of the plume head by the northward-moving Vancouver slab.

We suggest that a south-to-north change from an older cratonic crust with a thicker lithospheric mantle to a younger, more oceanic crust with a thinner lithospheric mantle (fig. 5) controlled the surface eruption of flood basalts from the plume (Zoback and Thompson, 1978; Pierce and Morgan, 1992; Zoback and others, 1994; Parsons and others, 1994; Takahahshi and others, 1998). As noted by Hooper (1997), nearly all of the Columbia River basalts erupted through fissures in thinner lithosphere made up of accreted oceanic crustal material. The earliest eruptions occurred along a north-south suture on the west side of the Precambrian crust and perpendicular to the minimum principal stress of the regional midMiocene state of stress (Zoback and others, 1994) and parallel to a Miocene back-arc spreading system (Zoback and others, 1981; Parsons, 1995). This denser, more mafic crust would facilitate basaltic melts rising to the surface and being erupted as (1) the denser crust increases the lithostatic pressure per crustal unit depth on the magma chamber, and (2) the mafic material is more refractory and thus less likely to 
melt. That the plume head uplift resulted in north-south rifting rather than the classic tensional rifts at 120 degree angles appears to relate to this east-west orientation of the minimum principal stress.

The extent of flood basalt now appears to include northern California and the Lovejoy Formation dated about $16 \mathrm{Ma}$ (Wagner and Saucedo, 1990; Page and others, 1995). Wagner (oral commun., 1999) estimates the volume of this basalt to be near $75,000 \mathrm{~km}^{3}$, including much basalt beneath the northern Sacramento Valley.

The northern Nevada rift zone was intruded by 14- to 17-Ma mafic magmas (Zoback and Thompson, 1978; Zoback and others, 1994). This extension zone continues northward to the feeder dikes of the Oregon Plateau and Columbia River flood basalts and southward along the extension of the northern Nevada rift into southern Nevada (Blakely and Jachens, 1991) and may include the 14- to 17-Ma rhyolites of southern Nevada. All together, these extensional features form the 1,100-km-long, 17-Ma NevadaOregon rift zone and centers on the inferred initial sublithospheric position of the Yellowstone plume head (Pierce and Morgan, 1992). Although feeder dikes for the Columbia River flood basalts are as much as $500 \mathrm{~km}$ north of this inferred center, White and McKenzie (1989) note that if mantle plumes coincide with active rifts, large-volume basalt eruptions can extend along rifts for $2,000 \mathrm{~km}$ (half distance $=1,000 \mathrm{~km}$ ). Although some plume heads are associated with radial dikes extending thousands of kilometers (Thompson, 1998), the linear N. $20^{\circ}-25^{\circ} \mathrm{W}$. Nevada-Oregon rift zone indicates that at $17 \mathrm{Ma}$ from eastern Washington to southern Nevada, the least principal stress was horizontal and oriented N. $65^{\circ}-70^{\circ} \mathrm{E}$. (Zoback and Thompson, 1978; Christiansen and McKee, 1978; Zoback and others, 1994).

Figure 5 shows modern geologic and geophysical characteristics along a north-south cross section parallel to the 14-to 17-Ma Nevada-Oregon rift zone (A-A', fig. 1). West of the ${ }^{87} \mathrm{Sr} /{ }^{86} \mathrm{Sr} 0.704$ line is young, mafic oceanic terrane in Oregon and Washington in the area of flood basalt extrusion. East of the ${ }^{87} \mathrm{Sr} /{ }^{86} \mathrm{Sr} 0.706$ line is Precambrian, continental crust in southern Nevada. General differences along the north-south section are as follows using McDermitt as the midpoint: Transect A shows basalts occurring in the farthest north segment; rhyolites, basalts, and tuffaceous sediments are exposed in the middle with trachybasalts exposed farther south; mafic intrusives with rhyolites occur in the southernmost segment. Transect B shows the terrane to the north as mostly Mesozoic and younger mafic oceanic and oceanic accreted terranes and the terrane to the south as increasing in age from a Paleozoic magmatic arc (Elison and others, 1990) to an interval along the Sr 0.706 line between a Paleozoic arc (to the west) and late Proterozoic sedimentary rocks (to the east; Link and others, 1993). Transect C shows that heat flow has a broad culmination over the inferred position of the plume head near the Nevada-Oregon border. Transect $\mathrm{D}$ shows terrain altitude changes from north to south: higher terrain in Canada descending to about $300 \mathrm{~m}$ on the Oregon-Washington border, then a bench above 1,500 $\mathrm{m}$ in southern Oregon and northern Nevada, to a culmination in central Nevada at about $2,400 \mathrm{~m}$, and finally a decrease to about $300 \mathrm{~m}$ in southern Nevada. Transect $\mathrm{E}$ is the average of complete Bouguer gravity anomaly values based on stacking (averaging) of the five parallel profiles centered on A-A' (fig. 1). The averaged profile shows prominent steps near the Washington-Oregon border and in southern Nevada separated by a major low (Saltus and Thompson, 1995).

Transect $\mathrm{F}$ is a two-dimensional model of the gravity profile. The southern boundary of anomalous asthenosphere on it is based on seismic, heat-flow, and isotopic constraints (Saltus and Thompson, 1995); the northern boundary of anomalous asthenosphere is based, by analogy, on the position of the complementary step in gravity and topography near the Washington-Oregon border. The crust/mantle boundary in the model is an average of three different western U.S. Moho maps presented in Geological Society of America Memoir 172 (Mooney and Weaver, 1989; Pakiser, 1989; Braile and others, 1989). We have allowed the midcrustal interface between felsic upper crust and mafic lower crust to vary in order to fit the remaining anomalies. To aid understanding, we have used absolute densities, albeit these are somewhat arbitrary; the gravity model is only sensitive to lateral variations in relative density, not to the 
absolute values. The model indicates that the gravity data are consistent with the seismically determined average Moho, with our hypothesized anomalous hot or light asthenosphere (hot plume head and restite, both assumed to be $0.05 \mathrm{~g} / \mathrm{cm}^{3}$ lighter than regular asthenosphere, fig. 5), and with a crust which ranges from generally mafic (shown as lower crust) in the north to generally felsic (shown as upper crust) in the south.

Figure 6 illustrates schematically along a north-south axis how a spreading plume head 500-1000 km across (Hill, 1972) might interact along the section A-A' with crustal changes reflected by the ${ }^{87 / 86} \mathrm{Sr} 0.704$ and 0.706 lines (fig. 1). To the north of center is relatively thin, dense, accreted oceanic crustal lithosphere, whereas to the south of center is progressively older, more silicic, more continental crustal material (Kistler, 1983; Elison and others, 1990; Mooney and Braile, 1989; Camp, 1995, Link and others, 1993). The rising and spreading plume head (density of $3.25 \mathrm{~g} / \mathrm{cc}$ ) would undergo decompression melting above a depth of about $150 \mathrm{~km}$, producing a basaltic melt (density $3.0 \mathrm{~g} / \mathrm{cc}$ ) and also leaving a restite (also density $3.0 \mathrm{~g} / \mathrm{cc}$ ). North of the McDermitt area, voluminous flood basalts erupted through the Chief Joseph dike swarm that is associated with the foliated and sheared suture zone between the Precambrian continental crust on the east and the oceanic lithosphere and intraoceanic island arc terranes on the west (Hooper, 1997; Camp, 1995; Snee and others; 1995; Vallier, 1995) also delineated by the ${ }^{87 / 86} \mathrm{Sr} 0.704$ and 0.706 lines (fig. 1). As observed by Hooper (1997), a significant lithospheric signature is present in all but the earliest of the Columbia River basalts and, in fact, varies spatially through time. The Columbia River basalts can be divided into three basic subgroups of enriched subcontinental lithospheric mantle that were entrained into the plume head.

For the Mesozoic and younger oceanic accreted terrane north of the midpoint, plume-head material would flow towards higher areas or "thinspots" at the base of the lithosphere, thereby allowing for an increase in decompression melting and forming basaltic magmas (Thompson and Gibson, 1991; Sleep, 1990). According to Hooper (1997), the Columbia River basalts were mantle-generated magmas that had relatively long residence times in reservoirs at the base of the crust and that erupted periodically and rapidly through NNW-SSE-oriented fissures to form the voluminous flood basalts. Because crust in this area was relatively dense, thin, and weak, and was adjacent to a major tectonic boundary of thicker, more competent, continental lithosphere (Hooper, 1997), the basaltic magma would be readily able to rise to the surface where it formed flood basalts of the Columbia River and Oregon Plateau. As described by Camp (1995), basalt flows become younger to the north and reflect the northward spread of the plume head as it intersected the lithosphere and pancaked outward. In addition to the northward migration of basalt flows, Camp (1995) also documents a northward progression of uplift during Columbia River basalt time. Between 14 and $17 \mathrm{Ma}$, northward-directed compression formed the east-west Yakima folds and associated thrusts (Hooper, 1990; Reidel and others, 1989), also consistent with plume head uplift from the south.

Magmatism from near and to the south of the Nevada-Oregon border was different from the flood basalts farther north (fig. 1): (1) rhyolites and basalts erupted in the region of the northern Nevada rift, (2) trachybasalts erupted in the central area, (3) unexposed basaltic dikes, inferred by observed magnetic anomalies, and isolated rhyolitic volcanic fields are in the south (Zoback and others, 1994). We think the following processes occurred beneath this area: decompression melting generated hot basalt that rose into the silicic crust where, due to the higher melting temperature of basalt, heat from the basaltic melt produced silicic magmas that then rose higher in the crust to form high-level magma chambers, from which erupted rhyolitic ignimbrites and lava flows.

Undoubtedly, the cross section along A-A' would have been somewhat different at $17 \mathrm{Ma}$. In particular, in northern and central Nevada, the lithosphere was probably thicker and has been subsequently thinned by basin and range extension. A significant amount of basaltic underplating, which we associate with the starting plume, has thickened the crust near the Moho in Nevada (Thompson and 


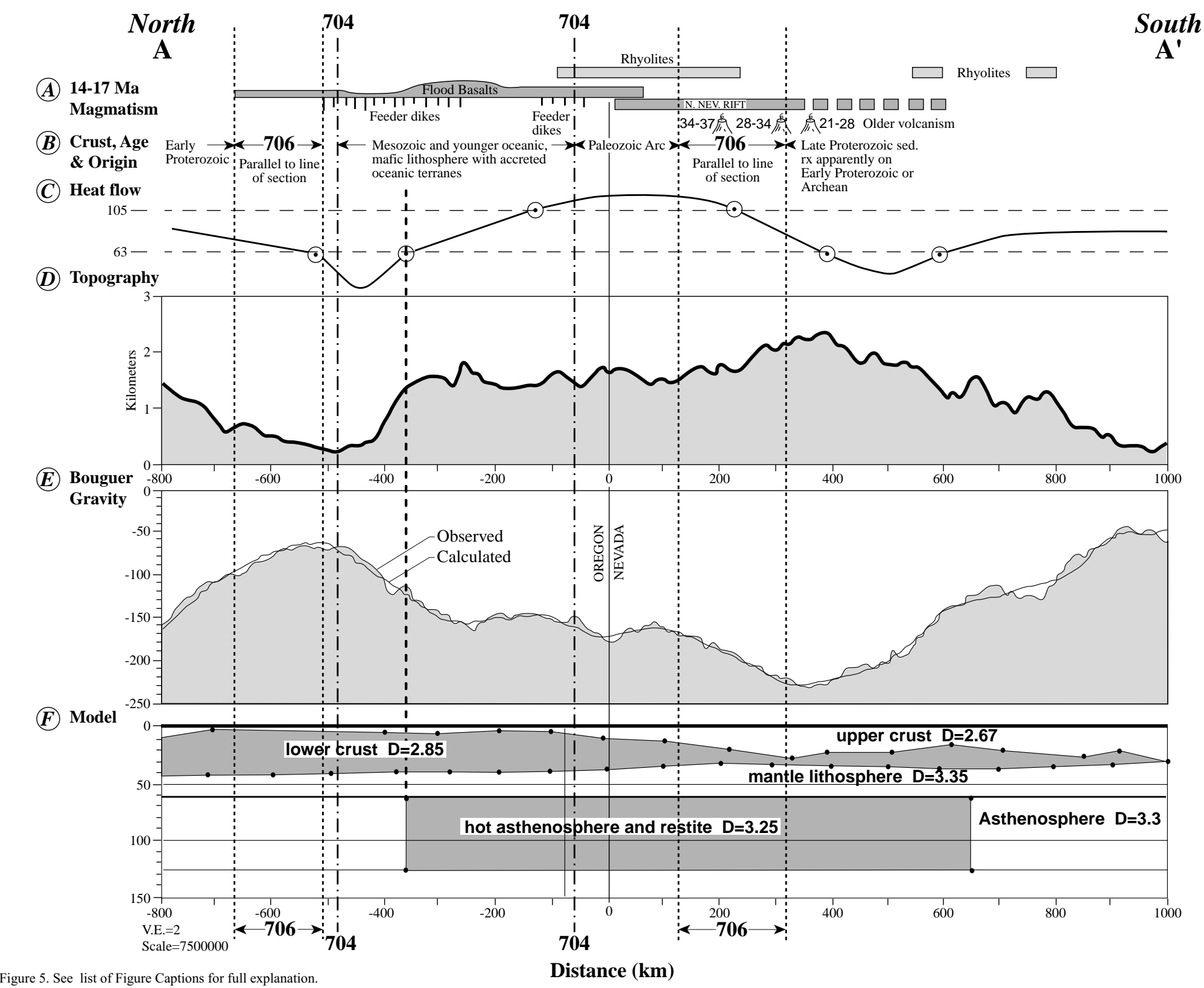




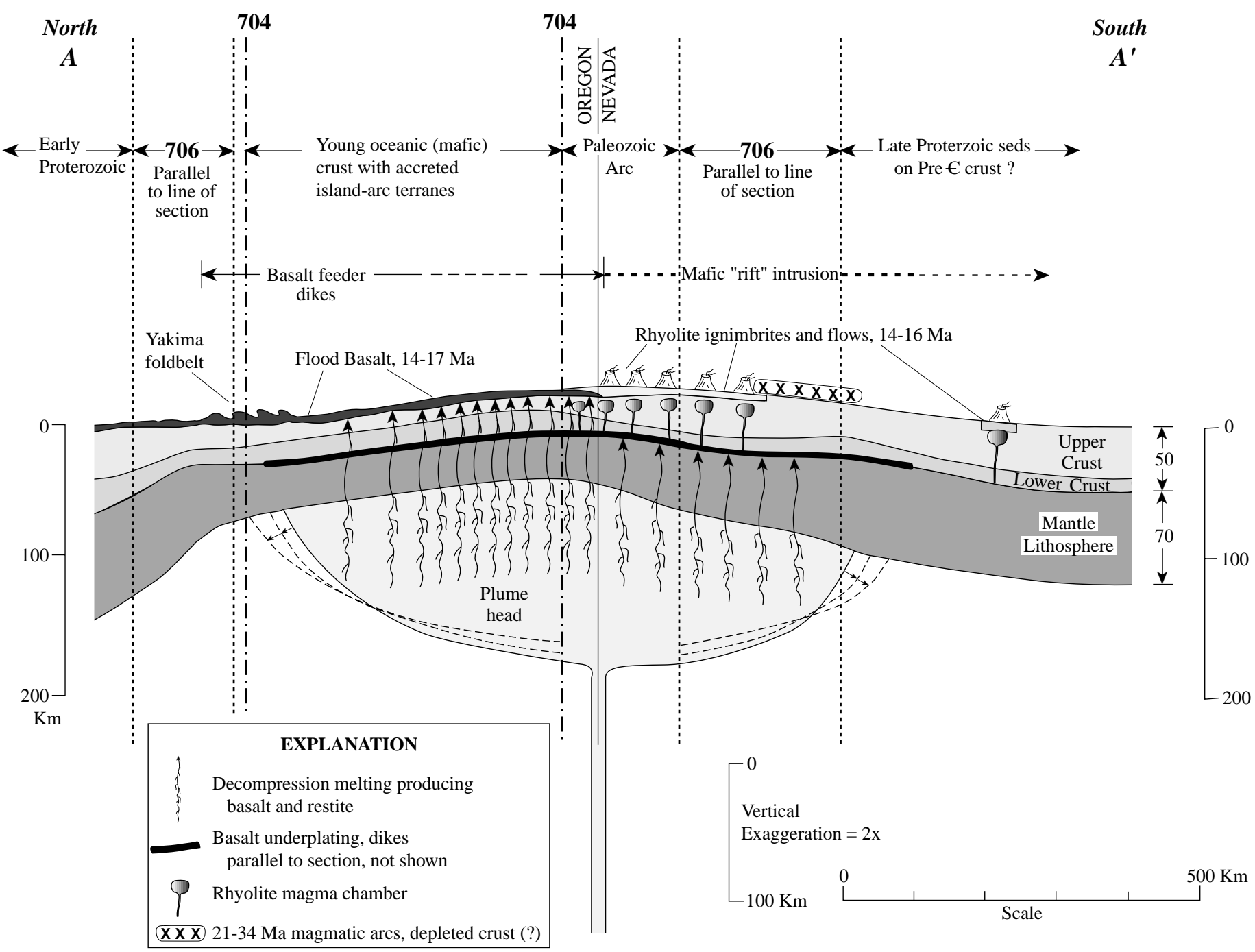

Figure 6. Geologic cartoon along line of section A-A' showing emplacement of postulated Yellowstone plume head. The plume head spreads out (pancakes, mushrooms) upon rising into the lithosphere, but it can rise further beneath the thinner lithosphere (young thin mafic crust and lithospheric mantle) beneath Oregon. Decompression melting (squiggly vertical lines) produces basalt magma that rises upward and interacts differently with the crust: (A) in Oregon, magma rises through the dense, more oceanic crust, and surfaces as the Columbia River and Oregon Plateau flood basalts, and (B) in Nevada and southern Oregon, basalt magma melts silicic lower crustal material that then rises into upper crust forming magma chambers (oval pods) and rhyolitic ignimbrite eruptions, shown as volcanoes, and (C) in northernmost Nevada and southern Oregon, both processes have operated. The restite from decompression melting remains in the mantle but is buoyant and contributes to long-lasting uplift (Morgan and others, 1995). At the time of emplacement, doming above the plume head may be 1-2 km (exaggerated in drawing). The northward gravitational push from this doming may have produced the Yakima fold belt near the northern end of the section. 
others, 1989). Crustal thickness may also have been thinner to the north before basaltic underplating associated with the 15-Ma and younger volcanism and the mantle lithosphere was likely thin beneath this young oceanic terrane. The hot, spreading plume head may have thinned the mantle lithosphere by thermal and mechanical erosion. Because topographic changes also have transpired over the last 17 m.y., the area above the plume head would have been topographically higher when the plume head first intersected the North American plate at 17 Ma than today. As suggested by Parsons and others (1994), the one$\mathrm{km}$ high present topography centered on McDermitt results from the residual effect of low-density Yellowstone plume material.

The plume head and associated Nevada-Oregon rift are spatially near the center of the active Basin and Range (fig. 4). We suggest a causal relationship exists between the inferred plume head and changes in the Basin and Range. Upon impact with the lithosphere, the plume head would decrease its ascension rate; this impact is associated in time and space with a change in Basin and Range extension and volcanism. While not advocates of a plume origin for this region, Christiansen and Yeats (1992) note, "The bimodal rhyolite-basalt magmatism of the Great Basin region is mostly younger than $17 \mathrm{Ma}$, following a widespread magmatic lull. By about $17 \mathrm{Ma}$, significant uplift had begun to be the dominant factor in the 1,600-km region that encompassed the Great Basin Region, the Columbia Intermontane region, and surrounding areas." For the 14-10-Ma interval, they write (p. 388 and Plate 7): "Regional extension in the continental interior changed to widely distributed normal faulting between about 14 and 10 Ma with accelerated uplift of the region from the Sierra Nevada to the High Plains."

Furthermore, northward migration of the source of flood basalts is represented in the spreading of the plume head (Camp, 1995). The remarkable N. $20^{\circ}-25^{\circ} \mathrm{W}$. orientation of the 1,100-km Oregon-Nevada rift zone indicates the minimum principal stress over this great length at $17 \mathrm{Ma}$ was about N. $65^{\circ}-70^{\circ} \mathrm{E}$. and subparallel to the west coast (Zoback and Thompson, 1978; Zoback and others, 1994).

\section{SOUTHERN OREGON RHYOLITE BELT AND THE PLUME HEAD}

Many have suggested that the southern Oregon rhyolite belt appears to contradict the plate-tectonic Yellowstone hotspot hypothesis in that it is a similar-aged volcanic progression that advances WNW across southern Oregon (MacLeod and others, 1976; Christiansen and Yeats, 1992, p. 381-382). The vector of this progression makes a 120-degree angle with the vector of the SRP-YP volcanic progression (fig. 1). Both emanate from the tri-state boundary area and have similar ages. Pierce and Morgan (1992, p. 32-33) note significant differences in the rhyolitic volcanism between the eastern SRP-YP trend and the southern Oregon trend that suggest different processes for the two progressions. Differences in the two volcanic provinces include the time of inception (the southern Oregon belt began about $10 \mathrm{Ma}$ and McDermitt erupted at 16.1 Ma); the style of volcanism (small rhyolitic domes and small-volume ignimbrites are typical in southern Oregon whereas large-volume ignimbrite eruptions are typical in the SRPYP province), and the volcanic migration rates. The Brothers strike-slip fault zone forms the northern part of the southern Oregon rhyolite trend. It also separates basin and range and associated extension on the south from the High Lava Plains with much less extension on the north. The map pattern of the Brothers fault zone (Walker and others, 1981; Pezzopane and Weldon 1993) is represented by short, small-offset, normal faults that are arranged in en echelon patterns oriented 10-20 degrees clockwise from the overall Brothers fault-zone trend. These extensional openings are associated with right lateral shear that may have provided conduits for volcanic eruptions. Draper (1991) suggests that both the spreading Yellowstone plume head and the activity on the Brothers fault zone started in northern Nevada-southern Oregon and migrated to the WNW. Volcanism followed this WNW migration of fault activity and plume spreading.

Some possible mechanisms that might explain the northwesterly volcanic progression in southern 
Oregon are: (1) counterflow associated with the WNW flow at the base of the lithosphere; (2) plume spreading (Sleep, 1997); and (3) the "up-and-out-welling" at the edge of a hot, thick body that might produce a WNW drag (fig. 7). A mechanism that might drag the western margin of the Yellowstone plume head further westward and produce the volcanic trend observed in southern Oregon is the counterflow or backflow occurring in the acute angle between the descending Vancouver slab and southwest-advancing North American plate (Draper, 1991). In addition to this counterflow, Eugene Humphreys (oral commun., 1997) and others suggest a thermal convective upwelling along the gradient of the edge of any hot mass in the mantle.

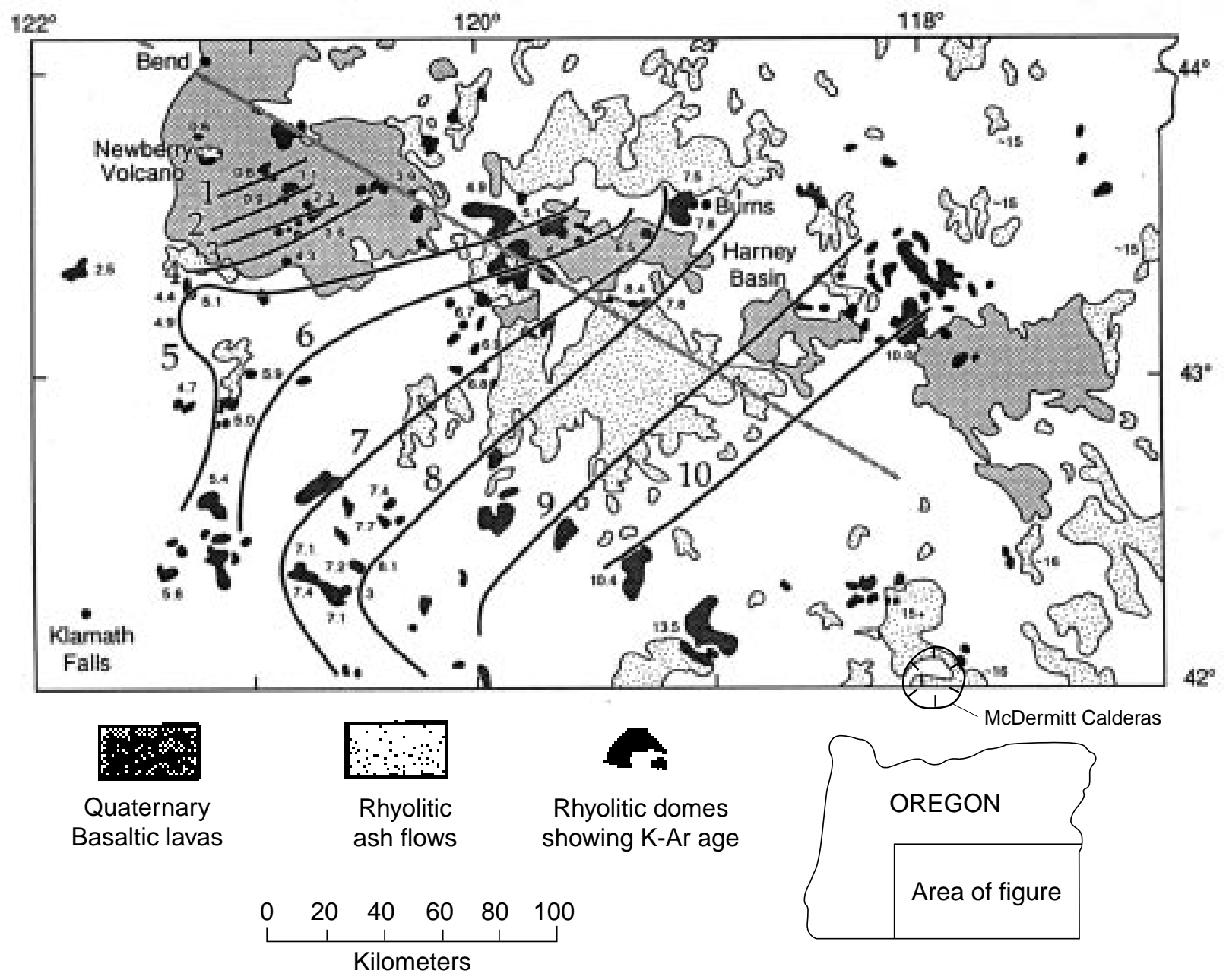

Figure 7. Age progression of silicic lava domes of the southern Oregon rhyolite belt. This figure shows upper Miocene and younger volcanic rocks and is copied from Christiansen and Yeats (1992, fig. 55). The rhyolite domes and their ages were shown by MacLeod and others (1976) to have such a systematic northwest decrease in age that ages could be contoured in one-million-year increments. This northwest age progression is a key argument against a plume origin for the Yellowstone hotspot (Lipman, 1992; Christiansen and Yeats, 1992). See Figure 9 for our suggestions about how the southern Oregon rhyolite belt might be reconciled with a thermal plume origin of the Yellowstone hotspot. Both the southern Oregon rhyolite belt and the Yellowstone hotspot track start in the region near McDermitt, but they become younger in nearly opposite directions at the same time. The silicic domes (dark) form two belts that trend N. $75^{\circ} \mathrm{W}$. The northern belt ends at Newberry caldera and parallels the Brothers fault zone (wide gray line) which is actually a complex en echelon pattern of normal faults whose trend of about $10^{\circ}$ clockwise to the overall pattern (Walker and Nolf, 1981) suggests a right lateral component (Pezzopane and Weldon, 1993). Between 10 and $17 \mathrm{Ma}$, ignimbrites and other silicic volcanism are widespread in the southern Oregon, northern Nevada and southwestern Oregon area (fig. 1; Pierce and Morgan, 1992;) but have no systematic progression with age in southeast Oregon (MacLeod and others, 1976, p. 470). 
Draper (1991) notes that no younger basalts overlie the Columbia River basalts. He attributes this to a combination of (1) magma reservoir depletion exhausted by the eruption of the Columbia River and Steens Mountain basalts and (2) extension beginning at about $10 \mathrm{Ma}$ that forced the plume head to spread out laterally at the base of the crust. This process resulted in abbreviated magma residence times and generated primitive HAOT (high-alumina olivine tholeiitic) magmas to the west of the Columbia River basalts. Draper (1991) suggests that as extension increased with time, smaller volumes of primitive magmas erupted. According to Draper (1991), the processes of extension combined with a laterally expanding plume head under a crust depleted in low-melting-point components. The result produced decreasing volumes of rhyolitic material over time. The WNW progression of silicic activity in the southern Oregon belt (figs. 7 and 8) was concentrated along the edge of the westward-expanding plume head influenced by the sinking Vancouver slab.

In contrast to this minor rhyolitic activity in southern Oregon, large volumes of rhyolitic ignimbrites, tephra, and lavas erupted along the SRP during this comparable interval of time (Bonnichsen, 1982; Perkins and others, 1998; Morgan and others, 1997; Morgan and others, 1984; Morgan and McIntosh, 2001; Christiansen, 1984). The northeast progression of rhyolitic volcanism in the SRP-YP has been attributed to the North American plate directly overriding the chimney or tail phase of the thermal plume (Pierce and Morgan, 1992) that melted a continuous supply of undepleted crustal material (Draper, 1991).

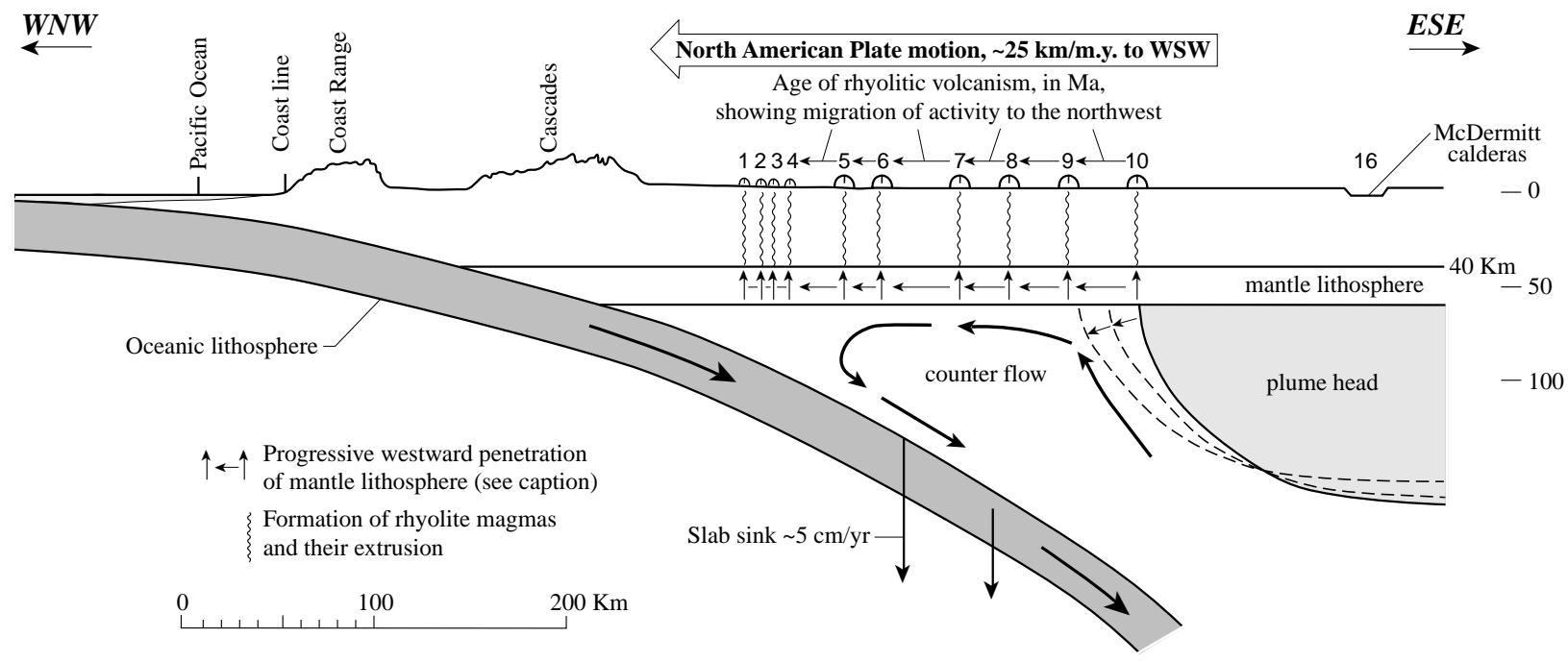

Figure 8. Geologic sketch (after Draper, 1991) along the southern Oregon rhyolite belt parallel to the trend of the Brothers fault zone. The mounds numbered 10 to 1 represent contours on the age or rhyolitic volcanism in Ma (MacLeod and others, 1976). Following Draper (1991), we suggest several factors may have acted separately or in combination to produce penetration of mantle lithosphere by basaltic melts to form rhyolite magma from crust: (1) cracking of mantle lithosphere by westward migration of activity on Brothers fault zone, (2) westward spreading of plume head, and (3) thermal erosion of mantle lithosphere associated with counterflow. Fracturing of the lithosphere along the Brothers fault zone (MacLeod and others, 1976; Carlson and Hart, 1987; Pezzopane and Weldon, 1993) appears to have provided the conduits for volcanism as well as its overall northwest trend. The most reasonable mechanism for the northwest progression of rhyolitic volcanism may be a northwest progression of faulting to form the Brothers fault zone. Such a northwest progression of faulting might have been accompanied by a northwestward migration of plume head material aided by both general outward migration of the plume head, and by counter flow between the Vancouver slab and North American plate (Draper, 1991). If the two proceeded together, the faulting may have caused fracturing of the mantle lithosphere permitting the erosion and stooping of the mantle lithosphere (a mechanism suggested by George Thompson, oral commun., 1998) and thus forming an inverted channel enhancing both outward (northwestward) plume head flow and decompression melting by thinning of the lithosphere. Although Draper (1991) drew a similar diagram, we include this version because many have argued that this northwestward volcanic progression negates the Yellowstone hotspot as a mantle plume, and we think these factors offer a mantle-plume compatible explanation. The geometry of the subducting slab is based on a fairly well controlled section by Parsons and others (1998) near the Oregon-Washington border. 
In conclusion, we concur with Draper (1991) that the southern Oregon rhyolite belt may reflect NW migration of either faulting or spreading of the Yellowstone plume head and that this progression does not necessarily negate the SRP-YP as a hotspot track of a thermal mantle plume.

\section{PLUME-HEAD UPLIFT AND ASSOCIATED CLIMATE PATTERNS}

Plume heads are expected to cause uplift of one kilometer or more and have diameters of 1,500 to $2,500 \mathrm{~km}$ (Hill and others, 1992). We estimate the Yellowstone plume head was originally a 400-kmdiameter sphere. A considerable size is suggested by the 15-17-Ma volcanic activity along the 1,100-km length of the Nevada-Oregon rift zone. Parsons and others (1994, and Tom Parsons, written commun., 1998) consider a minimum $800-\mathrm{km}$ diameter for the flattened plume head based on the current mass deficit in the upper mantle that extended over much of Nevada and parts of Utah and Oregon. Given the elongate pattern of tectonic and volcanic activity aligned subparallel to the Precambrian margin of the North American plate (Camp, 1995) as well as parallel to the back-arc margin inland from the Pacific Ocean (Zoback and others, 1981; Parsons, 1995), we favor (fig. 9) an elongate north-south spreading plume head similar to that proposed by Camp (1995).

Within the Columbia River basalts (fig. 9 and table 1), northward offlap of basalt units with time is shown by Camp (1995, fig. 4) to reflect south-to-north migration of uplift, with local uplift rates of about $2 / 3 \mathrm{~mm} / \mathrm{yr}$. This parallels the northward migration of Columbia River basalt source areas (Camp, 1995).

Estimates of past altitudes are difficult to reconstruct, but a modern leaf-morphology technique based on paleo-enthalpy differences between sea level and inland localities has promising results (fig. 9 and table 1). From detailed analysis of leaf physiognomy, Wolfe and others (1997) suggest that at about 15-16 Ma the surface of west central-Nevada was more than $1 \mathrm{~km}$ higher than now. We have reservations about this technique, in part because its results conflict with numerous studies that we find of merit for late Cenozoic uplift in the Colorado Rockies. But we do find this result for Nevada surprisingly compatible in our altitude estimate, general location, and age for plume-head uplift. Further east, an Eocene fossil-leaf flora is compatible with eastward migration of Yellowstone hotspot uplift: just south of the present location of the Yellowstone hotspot is a 50-Ma locality that is estimated to have been elevated 0.9 $\mathrm{km}$ to its present altitude sometime in the last $50 \mathrm{Ma}$ and therefore after the Laramide orogeny (fig. 9; Wolfe and others, 1998). This is compatible with uplift associated with the hotspot as it migrated $650 \mathrm{~km}$ from the plume-head area at $16 \mathrm{Ma}$ to its current position at Yellowstone at $2 \mathrm{Ma}$.

Our hypothesized uplift of one km over a north-south distance of 1,000 km (fig. 9) should have a significant effect on local weather patterns. The expected effect would be increased precipitation on the west side from the orographic moisture extraction of rising airmasses coming inland (eastward) from the Pacific Ocean and then orographic drying and aridity east of the crest as these airmasses descend the lee side of the uplift. A precipitation shadow might extend further inland (east) as far as the main moisture source was from the Pacific. This pattern is analogous to the present Sierra Nevada with a wet west side, a dry east side, and a precipitation shadow extending far eastward across the Great Basin.

The geologic history of the Tertiary Bozeman Group in the Montana-Idaho area suggests the climate became more arid about $15 \mathrm{Ma}$ at the time the plume-head uplift would have culminated (table 1 and fig. 9, locations 9 and 10; Thompson and others, 1982; Fields and others, 1985). In the Yellowstone Valley north of Yellowstone Park, 15-Ma saline lake deposits with gypsum and anhydrite formed because of aridity. Furthermore, associated rodent fossils at nearby localities suggest aridity was more severe than at $20 \mathrm{Ma}$ (table 1, location 11; Barnosky and Labar, 1989).

Paleobotanical transects from eastern Washington and Oregon to the Rocky Mountains (fig. 9 and table 1, locality 13; Leopold and Denton, 1987,) show clear drying inland, but do not show any compelling evidence for plume-head uplift. Between 12-17 Ma, vegetation reconstructions show in eastern 


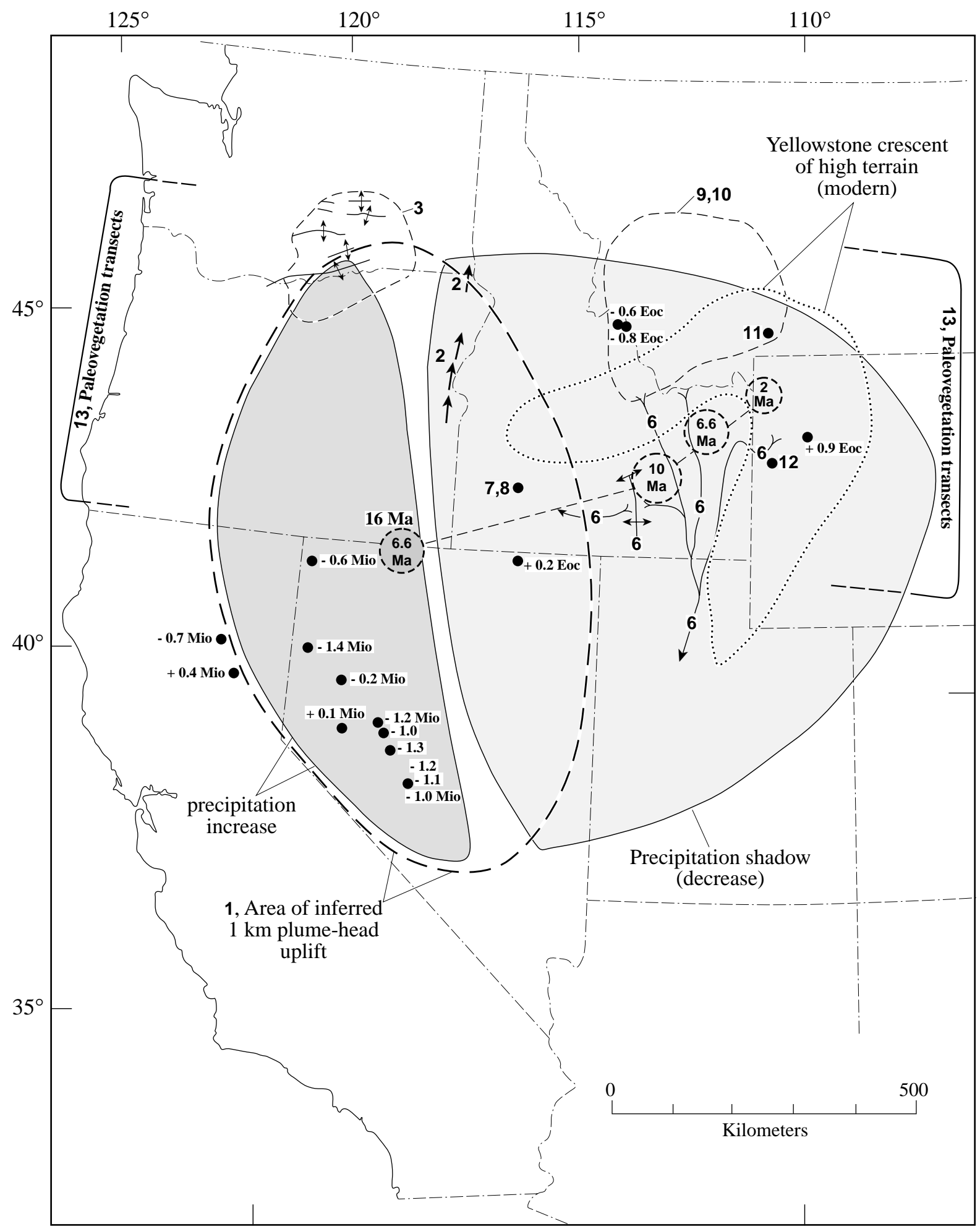

Figure 9. Uplift and climatic patterns that may relate to Yellowstone plume (both head and tail). The dashed line shows the pancaked plume with a diameter suggested by Parsons and others (1994) of about $400 \mathrm{~km}$ but elongated north south as suggested by Camp (1995) parallel to the Nevada-Oregon rift zone. Table 1 describes the various localities, areas, and transects shown here. One of the main climatic parameters listed is orographic dryness (light shading) in the lee of the inferred Yellowstone plume-head uplift. In general, observations of uplift and climate are compatible with uplift above the plume head followed by uplift migrating to the east associated with the plume tail (chimney) to the "Yellowstone crescent of high terrain" associated with the present plume tail (Pierce and Morgan, 1992) or a similar 650-m-high altitude anomaly that Smith and Braille (1993) associated with the current Yellowstone hotspot. 
Table 1. A sampling of possible indicators of uplift, altitude, precipitation shadow, and climate that may be related to Yellowstone hotspot plume uplift.

\begin{tabular}{|c|c|c|c|c|c|c|}
\hline Loc. & Age & Unit & \multicolumn{3}{|c|}{ Comments } & References \\
\hline 1 & $\sim 15 ? \mathrm{Ma}$ & $\begin{array}{l}\text { Low density } \\
\text { anomaly in the } \\
\text { mantle }\end{array}$ & \multicolumn{3}{|c|}{$\begin{array}{l}\text { Large, low-density anomaly in the mantle interpreted to be Yellowstone plume head. Diameter about } 800 \mathrm{~km} \\
\text { and associated with active basin and range. }\end{array}$} & $\begin{array}{l}\text { Parsons and } \\
\text { others, } 1994\end{array}$ \\
\hline 2 & 17.5-14 Ma & $\begin{array}{l}\text { Columbia River } \\
\text { basalt }\end{array}$ & \multicolumn{3}{|c|}{ Offlap and thickness of subsequent CRB units indicate south to north uplift, locally at a rate of $0.67 \mathrm{~mm} / \mathrm{yr}$. } & Camp, 1995 \\
\hline 3 & $\begin{array}{l}17-14 \mathrm{Ma} \\
\text { and } \\
\text { continuing }\end{array}$ & Yakima fold belt & \multicolumn{3}{|c|}{$\begin{array}{l}\text { The Yakima fold belt on the northern margin of the CRB was formed by south to north compression. CRB flows } \\
\text { were being deformed shortly after their emplacement. We here suggest that the age and pattern of deformation } \\
\text { are consistent with Yellowstone plume head uplift and north-directed gravitational forces on the north flank of the } \\
\text { uplift (perhaps others have already suggested this). }\end{array}$} & $\begin{array}{l}\text { See Reidel and } \\
\text { others (1989) for } \\
\text { age and geometry } \\
\text { of structure. }\end{array}$ \\
\hline 4 = "Mio" & $\sim 14-16 \mathrm{Ma}$ & $\begin{array}{l}\text { Middle Miocene } \\
\text { leaves }\end{array}$ & \multicolumn{3}{|c|}{$\begin{array}{l}\text { Paleobotanical analysis using leaf physiognomy of middle Miocene assemblages indicates subsequent } \\
\text { subsidence (-) or uplift of stated amount in km. "When the standard error is applied to two coeval sites, the } \\
\text { combination of the two errors produces a standard error in the estimated difference in altitude of } \sim 760 \mathrm{~m} . "\end{array}$} & $\begin{array}{l}\text { Wolfe and others, } \\
1997\end{array}$ \\
\hline $5=$ "Eoc" & $\sim 40-50 \mathrm{Ma}$ & Eocene leaves & \multirow{2}{*}{\multicolumn{3}{|c|}{$\begin{array}{l}\text { Paleobotanical analysis using leaf physiognomy of Eocene assemblages indicates subsequent subsidence (-) or } \\
\text { uplift of stated amount in km. } \\
\text { Drainage divide on present Snake River Plain } 75 \mathrm{~km} \text { east of Twin Falls with drainage west of this divide down } \\
\text { present Snake River Plain and out towards California, and east of this divide drainage from Jackson Hole and } \\
\text { north of SRP southward into present Bonneville Basin. This suggests an ancestral high (hotspot?) east of Twin } \\
\text { Falls in the late Miocene. }\end{array}$}} & $\begin{array}{l}\text { Wolf and others, } \\
1998\end{array}$ \\
\hline 6 & 9?-5? Ma & Late Miocene & & & & $\begin{array}{l}\text { Taylor and Bright, } \\
1987\end{array}$ \\
\hline 7 & 5-9.5 Ma & Chalk Hills Fm. & \multicolumn{3}{|c|}{$\begin{array}{l}\text { Fish ecology and oxygen-isotope analysis on fish otolith suggest warm, moist climate with milder winters }\left(16^{\circ} \mathrm{C}\right. \\
\text { warmer than present) and cool summers ( } 1^{\circ} \text { cooler than present). Oxygen isotope (SMOW) calculated for water } \\
-15.5 \text { per mil and annual cycle in fish from }-16.6 \text { to }-13.5 \text { per mil. }\end{array}$} & $\begin{array}{l}\text { Smith and } \\
\text { Patterson, } 1994\end{array}$ \\
\hline 8 & 5-9.5 Ma & Chalk Hills Fm. & \multicolumn{3}{|c|}{$\begin{array}{l}\text { Water in glass spheres has } \delta \text { D value of }-147 \text { per mil, whereas present-day meteoric water at site has value of }-125 \\
\text { per mil. This value is as high as that for drainages in the highest country at the upper end of the hotspot track in } \\
\text { the mountains surrounding Yellowstone (Irving Friedman, written commun., 1998), suggesting the possibility } \\
\text { that this area was much higher at the time of deposition. }\end{array}$} & $\begin{array}{l}\text { Friedman and } \\
\text { others, } 1993\end{array}$ \\
\hline 9 & $16 \mathrm{Ma}$ & Bozeman Group & \multicolumn{3}{|c|}{$\begin{array}{l}\text { Change from a wetter to a more arid climate at about } 16 \text { Ma may reflect inception of precipitation shadow from } \\
\text { plume head. }\end{array}$} & $\begin{array}{l}\text { Fields and others, } \\
1985\end{array}$ \\
\hline 10 & $\sim 15 \mathrm{Ma}$ & $\begin{array}{l}\text { Six Mile- } \\
\text { Renova } \\
\text { unconformity }\end{array}$ & \multicolumn{3}{|c|}{ Climate change from wet to dry $\sim 15 \mathrm{Ma}$ (and dry to wet $\sim 20 \mathrm{Ma}$ ) } & $\begin{array}{l}\text { Thompson and } \\
\text { others, } 1982\end{array}$ \\
\hline 11 & $15 \mathrm{Ma}$ & $\begin{array}{l}\text { Hepburn Mesa } \\
\text { Fm. } \\
\text { Barstovian }\end{array}$ & \multicolumn{3}{|c|}{$\begin{array}{l}\text { Saline lake deposit with gypsum and halite indicates aridity and drier than present. Rodent type suggests even } \\
\text { more arid than semiarid Arikareean. May be in precipitation shadow of plume uplift to west. }\end{array}$} & $\begin{array}{l}\text { Barnosky and } \\
\text { Labar, } 1989\end{array}$ \\
\hline 12 & $\sim 8-6 ? \mathrm{Ma}$ & Camp Davis Fm. & \multicolumn{3}{|c|}{$\begin{array}{l}\text { Lake sediments rich in carbonate suggest dryness. Oxygen isotopes ( }-5.4 \text { to } 8.7 \text { per mil, SMOW) "are the lightest } \\
\text { yet reported for a nonmarine carbonate." Lake water estimated to be }-20.7 \text { to }-34.8 \text { per mil. SMOW and modern } \\
\text { precipitation to be }-16.5 \text { per mil, SMOW (-30 per mil oxygen SMOW converts to }-160 \text { per mil Deuterium). } \\
\text { Either much higher than present or in major precipitation shadow (of plume uplift?) or a combination of the } \\
\text { above. The similarity in age to the Chalk Hills Formation but the much lighter isotopes suggests this site may } \\
\text { have been in a precipitation shadow related to uplift of the plume tail. }\end{array}$} & $\begin{array}{l}\text { Drummond and } \\
\text { others, } 1993\end{array}$ \\
\hline 13 & \multirow{2}{*}{\multicolumn{5}{|c|}{ Transect from Pacific Coast inland to Rocky Mountains }} & \\
\hline & & & & & & \\
\hline 13a & $12-17 \mathrm{Ma}$ & $\begin{array}{l}\text { Barstovian/Late } \\
\text { Hemingfordian }\end{array}$ & $\begin{array}{l}\text { Deciduous hardwood forest and } \\
\text { Taxodium swamp }\end{array}$ & $\begin{array}{l}\text { Deciduous hardwood forest and } \\
\text { Taxodium swamp }\end{array}$ & $\begin{array}{l}\text { Montane conifer forest with steppe } \\
\text { openings. Precipitation shadow? }\end{array}$ & $\begin{array}{l}\text { Leopold and Denton, } \\
\text { 1987, Table } 7\end{array}$ \\
\hline $\begin{array}{c}13 \mathrm{~b} \\
\text { similar to } 4\end{array}$ & 8-12 Ma & Clarendonian & $\begin{array}{l}\text { Clarendonian } \\
\text { Montane conifer and deciduous forest, } \\
\text { Taxodium swamp }\end{array}$ & $\begin{array}{l}\text { Montane conifer and deciduous } \\
\text { forest }\end{array}$ & $\begin{array}{l}\text { Montane conifer forest with steppe } \\
\text { openings. Precipitation shadow? }\end{array}$ & $\begin{array}{l}\text { Leopold and Denton, } \\
\text { 1987, Table } 7\end{array}$ \\
\hline
\end{tabular}


Oregon/Washington, and northern Idaho- deciduous hardwood forest and Taxodium swamps; in central Wyoming and Colorado- montane conifer forest with steppe openings. Between 8-12 Ma, reconstructions show: in eastern Oregon/Washington, and southern Idaho - montane conifer forest and deciduous forests; in northwest Wyoming- montane conifer forests with steppe openings. The Rocky Mountain localities are permissible of a precipitation shadow in the lee of plume head uplift to the west

The following history of vegetation in the SRP area is compatible with decrease in altitude (Leopold and Wright, 1985) that may have followed plume head and tail related uplift: (1) Miocene- deciduous/ conifer forest; (2) Pliocene- conifer forest with some open grassland with increasing numbers of grazing horses; and (3) Pleistocene, steppe vegetation and alkaline lakes.

In Jackson Hole, <7.5- to 10.3-Ma lacustrine beds (Love and others, 1997) have carbonate that Drummond and others (1993) concluded had the lightest ${ }^{18} \mathrm{O} /{ }^{16} \mathrm{O}$ ratio yet recorded for nonmarine carbonate sequences (fig. 9 and table 1, locality 12). In the similar-aged 7-Ma Chalk Hills Formation in the western SRP (fig. 9 and table 1, locality 8), deuterium in glass spheres is 22 per mil lighter than modern water (Friedman and others, 1993), which may suggest that the western plain was higher at $7 \mathrm{Ma}$. Also from the Chalk Hills Formation, oxygen isotope studies of fish otolith vary from -16.6 to -13.5 per mil in water calculated to have been -15.5 per mil. These data also suggest the water source for the 7-Ma Chalk Hills Formation was at a higher than present elevation. Uplift associated with the inferred 7-Ma plume position near Pocatello (Pierce and Morgan, 1992) may have resulted both in higher terrain in the Chalk Hills area of the western SRP and orographically drier climates east of this highland resulting in very light oxygen isotopes in the Jackson Hole area. Amundson and others (1996) summarize for the western United States some available information on oxygen isotope distribution.

Using the regional distribution and paleobiogeography of mollusks, Taylor and Bright (1987, fig. 5) locate a late Miocene (5?-9? Ma) drainage divide near American Falls, Idaho (about 75 km east of Twin Falls) with drainage east of this divide going south into the present Bonneville Basin (fig. 9 and table 1, locality 6). Wood and Clemens (2001) also invoke a northeast shifting drainage divide to explain an increase in drainage basin size associated with a rise of Lake Idaho from a low about 6-7 Ma to a high near 5.5 Ma (their fig. 7).

\section{GENERAL CLIMATE HISTORY}

The marine record of climate change shows overall cooling throughout the Cenozoic, which in finer detail includes some steps, plateaus, and peaks (fig. 10). Coffin and Eldholm (1994, and references therein) show the correlation between the Columbia Plateau "large igneous province" and the 14-17 Ma Miocene warm interval, which was followed by cooling. The 14- to 17-Ma climatic optimum is recognized in deep-sea sites (fig. 10 shows compilation by Barron and Keller, 1982, fig. 1, and site 747 on Kerguelen Plateau by Wright and Miller, 1992). A major global warming at 18-15 Ma also is recognized on land by "dramatic northward movement of temperate deciduous forests north of the Arctic Circle in Alaska and northern Canada" (Thomas Ager, written commun., 1996). Hodell and Woodruff (1994) attribute this middle Miocene climatic optimum to the warming effect of carbon dioxide and other material associated with extrusion of the Columbia River flood basalts. Significant carbon dioxide emissions probably accompany flood basalt and other volcanic activity (Arthur and others, 1985; McClean, 1985, Leavitt, 1982, Rampino, 1991).

Self and others (1997) estimate that the volatile release from the Rosa unit of the Columbia River basalt introduced significant amounts of $\mathrm{S}, \mathrm{Cl}$, and $\mathrm{Fl}$ into the upper troposphere and possibly the lower stratosphere, thus significantly affecting the global atmosphere. Eruptions of the type, composition, and magnitude as that present in the Columbia River basalts, sustained over periods of years to decades, would have "strong, detrimental effects on global climate" (Self and others, 1997). After $14 \mathrm{Ma}$, the great 
majority of the total volume of the Columbia River basalt had been erupted (Baksi, 1989) and emissions of carbon dioxide associated with plume head volcanism decreased, compatible with the cooling of climate by $14 \mathrm{Ma}$.

Although uplifts effect climate patterns, Raymo and others (1988) and Raymo and Ruddiman (1992), postulate the largest effect on climate associated with uplift of the Himalayan-Tibet areas was through the reduction in carbon dioxide during enhanced silicate weathering of fresh material kept exposed by accelerated erosion on tectonically steepened terrain. Carbon-dioxide changes related to plume head volcanism and uplift is consistent with the climate history in the in the 17- to 10-Ma time interval shown in Figure 10 as follows: (1) carbon dioxide buildup in atmosphere associated with 15- to 17-Ma Oregon Plateau and Columbia River flood basalts, and (2) carbon-dioxide reduction associated with silicate weathering due to erosion and dissection of plume-head uplift starting about $15 \mathrm{Ma}$.

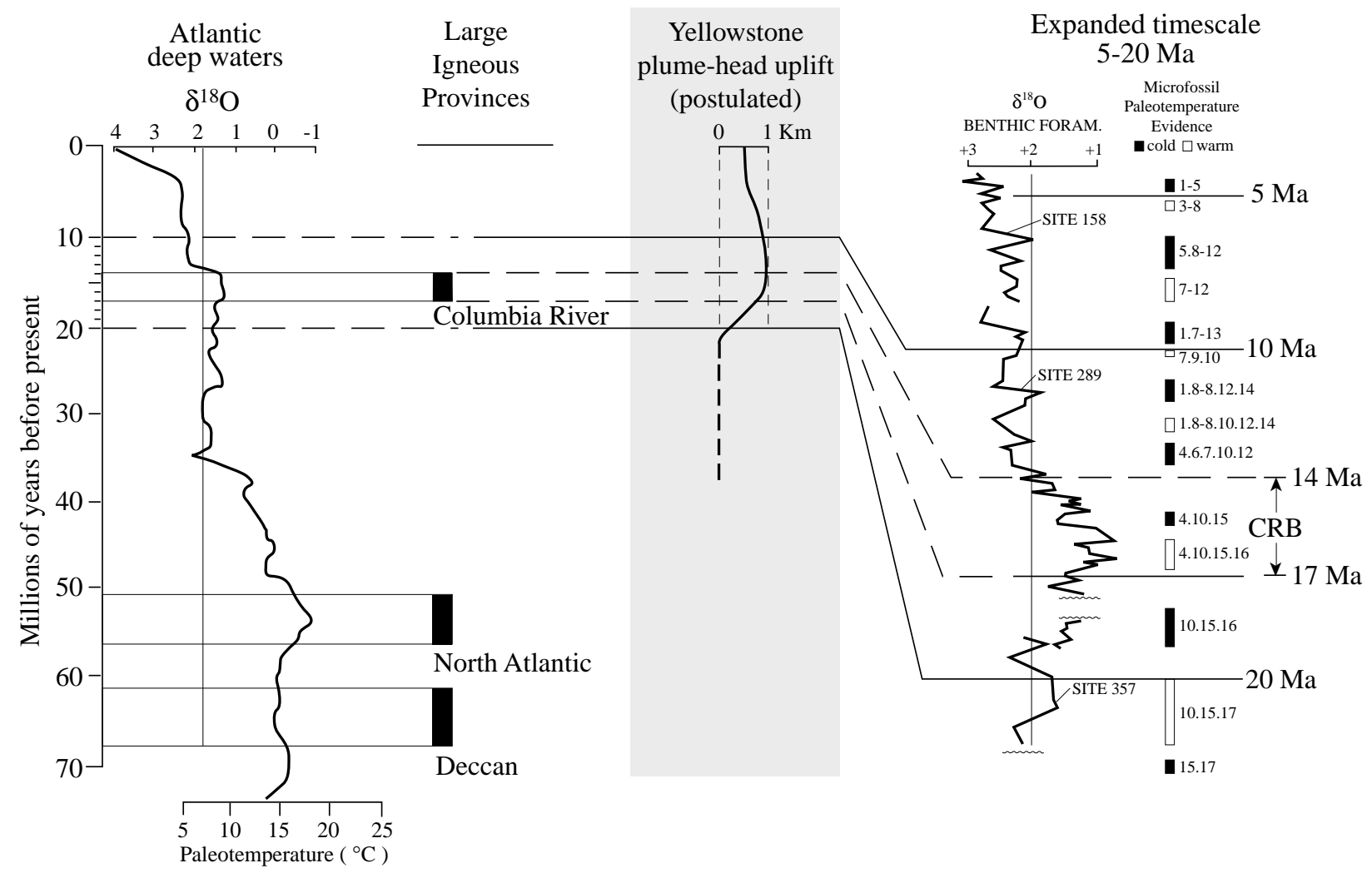

Figure 10. Temporal relations among Cenozoic climate proxies, "large igneous provinces" (flood basalts) and postulated Yellowstone plumehead uplift. Atlantic deep waters (after Miller and others, 1987, as shown in Barron and Baldauf, 1989). The about 14-17-Ma middle Miocene "climatic optimum" (expanded plot, right side from Barron and Keller, 1982) has been associated with the Columbia River-Oregon Plateau flood basalts (CRB, for example, Hodell and Woodruff, 1994). After the Miocene "climatic optimum," cooling continued eventually to the PliocenePleistocene ice ages. Uplift associated with the Yellowstone plume head is a candidate for a "plateau uplift" whose plume-head mechanism could produce significant late Cenozoic uplift (fig. 9). Global climatic modeling by Kutzbach and others (1989) and Ruddiman and others, (1997) shows that "plateau uplifts" could produce late Cenozoic climatic cooling in the Northern Hemisphere that might lead to the Plio-Pleistocene ice ages. Late Cenozoic Yellowstone plume uplift (head and tail) could also diminish atmospheric CO2 leading to cooling, by the mechanism of Raymo and Ruddiman (1992) and Ruddiman and others (1997). Plume-head uplift does not have the geophysical problem of a plausible mechanism of how the isostatic balance of the lithosphere could rapidly change that Molnar and England (1990a; $b$ ) used to challenge the validity of late Cenozoic "plateau uplifts". 


\section{DISCUSSION OF PLUME HEAD-UPLIFT AND CLIMATE}

Studies by Ruddiman, Kutzbach, and colleagues suggest that late Cenozoic plateau uplift could have forced changes that led to the "late Cenozoic climatic deterioration" that culminated in the Plio-Pleistocene ice ages (Ruddiman and Kutzbach, 1989; Kutzbach and others, 1989; Ruddiman and others, 1989). They suggested plateau uplift in southern Asia and the American West, including the Sierra Nevada, Colorado Plateau, Basin and Range, Rocky Mountains, and High Plains (Ruddiman and others, 1989). However, Molnar and England (1990a, b) strongly question the late Cenozoic uplift of the American West. Much new paleobotanical analysis using the methods of Wolfe (1993) or similar methods has also cast doubt on general uplift in the West and particularly that of the Rocky Mountains (Gregory and Chase, 1992) and the Colorado Plateau. Also, House and others (1998) conclude the Sierra Nevada has been high since the Cretaceous based on thermal history and apatite (U-Th)/He ages. In addition, Molnar and England (1990a) examine the geophysical basis of uplift and question evidence suggesting true uplift as distinct from isostatic uplift associated with erosion.

The mechanism of uplift associated with a plume head or tail does provide a driving process below the lithosphere to explain epeirogenic-type uplift. We suggest that broad plume-head uplift (see fig. 9) was substantial by about $17 \mathrm{Ma}$ and was followed by gradual subsidence in the head area. The uplift migrated northeastward to the present Yellowstone crescent of high terrain (fig. 9) that is associated with the current plume tail (Pierce and Morgan, 1992). The geoid anomaly that now centers on the Yellowstone Plateau (Pierce and Morgan, 1992; Pierce and others, 1992; Smith and Braille, 1993, fig. 7) and, more importantly, the larger plume-head uplift might provide a late Cenozoic broad uplift that could affect climate patterns in the ways modeled by Kutzbach and others (1989). Evidence (table 1) for uplift, migrating drainage divides, and an orographic precipitation shadow suggest uplift associated with the plume head and ensuing tail may have occurred. Much more complete analysis of existing and new evidence is needed to evaluate plume-head uplift and possible relations to climatic patterns, but we hope this brief outline suggests avenues for future research.

\section{CONCLUSIONS}

We were led to the hypothesis of a 17-Ma Yellowstone plume head by tracing the Yellowstone hotspot track back to the area of the McDermitt volcanic field on the Nevada-Oregon border. We think the Yellowstone hotspot track is best explained by a mantle plume particularly because of the following evidence (Pierce and Morgan, 1992): (1) the volcanism that progressed from $10 \mathrm{Ma}$ to $2 \mathrm{Ma}$ is coincident with both the rate and orientation predicted by plate motion, (2) the belts of faulting and uplift are oriented about this volcanic progression like the bow wave of a boat with uplift occurring in advance (northeast) of volcanism, (3) a large geoid anomaly centers on Yellowstone, (4) ${ }^{3} \mathrm{He} /{ }^{4} \mathrm{He}$ ratios near 16 suggest a deep mantle source, and, most important, (5) the scale of associated faulting and uplift is more than 400 $\mathrm{km}$ across suggesting a deep, sub-lithospheric process.

Upon backtracking the hotspot to its start near McDermitt, we find that a plume head (a sphere about $400 \mathrm{~km}$ in diameter) explains the following observations (fig. 1): (1) the much wider dispersal of 14- to 16-Ma rhyolitic volcanism than that after $10 \mathrm{Ma},(2)$ the association of the inferred plume head with the 14- to 17-Ma Columbia River and Oregon Plateau basalts, (3) the plume-head location near the mid-point of the 1,100-km-long, 16- to 17-Ma, Nevada-Oregon rift zone, and (4) no continuous manifestation of a hotspot before $17 \mathrm{ma}$.

If one accepts the Yellowstone plume head hypothesis, the following three topics merit attention.

1. Westward displacement of the plume head upward along the inclined Vancouver slab (figs. 2 and 3). Plate tectonic reconstructions suggest the rising plume head rose upward into the Vancouver slab. We 
suggest its buoyant rise was deflected westward by the up-to-the-west rise of the Vancouver slab. This could explain an unresolved problem with the hotspot track between the 10-Ma Picabo volcanic field and the 16-Ma McDermitt area that calls for a rate too high $\left(70 \mathrm{~km} / \mathrm{m} . \mathrm{y}\right.$ ) and a trend more easterly (about $20^{\circ}$ clockwise) than indicated by both the post-10-Ma progression of volcanism and faulting (about $2.9 \pm 0.5$ $\mathrm{km} / \mathrm{m}$.y to the $\mathrm{N} 54 \pm 5^{\circ} \mathrm{E}$ ) and the known rate and direction of North American plate motion (about 2.2 $\pm 0.8 \mathrm{~km} / \mathrm{m} . \mathrm{y}$. to the S $56 \pm 17^{\circ} \mathrm{W}$; Pierce and Morgan, 1992, p. 6).

2. The oblique transection of the craton margin by the plume head going from Mesozoic accreted oceanic lithosphere in the north to Precambrian craton in the south (figs. 5 and 6). Our best estimate is that the plume head contacted the lithosphere about 17 Ma near the Oregon-Nevada border beneath the McDermitt volcanic field. Reconstructions of crust and mantle lithosphere properties suggest a thinner, denser, oceanic lithosphere was present to the north in Oregon and Washington than in Nevada. This permitted the mantle plume head to migrate preferentially towards this "thinspot" and thus favor more decompression melting. The greater crustal density favored the eruption of the Columbia River and Oregon Plateau flood basalts. The 16-17-Ma Nevada-Oregon rift zone is defined by the N. $20^{\circ} \mathrm{W}$. orientation of the following about 16-17 Ma features: (1) the northern Nevada rift, (2) the extension of this rift into southern Nevada, and (3) the feeder dikes to the Columbia River and Oregon Plateau flood basalts. Although flood basalts are north of the inferred plume center, the plume is at the midpoint of this 16-Ma rift zone. Composition of erupted or intruded magmatic material can be explained by differences in crustal composition: (1) flood basalts are restricted to the oceanic, mafic crust and (2) rhyolites are restricted to more continental crust where the partial melt of mantle basalt melted silicic crustal material which rose upward to form magma chambers that erupted to produce rhyolite flows and ignimbrites, leaving the heat-supplying basalt at depth.

3. Plume-head uplift and associated climatic patterns (figs. 8 and 9). A plume head is expected to produce significant uplift. Based on several observations, we prefer roughly $1 \mathrm{~km}$ of uplift over an oblong northsouth ellipse of $1,100 \mathrm{~km}$. Paleobotanical analysis of leaves suggest that at $15 \mathrm{Ma}$, central and northern Nevada was about $1 \mathrm{~km}$ higher than present. A precipitation shadow is expected to occur east of this postulated uplift; evidence of marked aridity about $15 \mathrm{Ma}$ is found near the common boundaries of Montana, Wyoming, and Idaho. About $7 \mathrm{Ma}$, uplift associated with eastward hotspot migration is predicted to migrate to the area of the central SRP; paleo-mollusk studies suggest a drainage divide in this area near American Falls, Idaho, and other studies suggest aridity to the east of this uplift. The Yellowstone plume-head may provide a mechanism for regional uplift that is geophysically plausible. Notably, the plume-head mechanism can cause geologically rapid uplift without requiring crustal thickening. Modeling studies suggest this kind of uplift could contribute to late Cenozoic cooling leading to the ice ages (Kutzbach and others, 1989; Ruddiman and others, 1997).

A more thorough evaluation of the plume head hypothesis and its implications regarding (1) westward offset up the inclined Vancouver slab; (2) lithospheric changes along the Nevada-Oregon rift zone, and (3) uplift and associated climatic changes all require much additional study.

\section{ACKNOWLEDGMENTS}

We have discussed these ideas with many colleagues during the last few years. We have particularly benefited from discussions with George Thompson, Tom Parsons, Mike Coffin, Norm Sleep, Robert Duncan, Eugene Humphreys, Vic Camp, Alan Wallace, Anita Grunder, Scott Lundstrom, Margaret Hiza, Silvio Pezzopane, and Bob Thompson. We wish to thank Spence Wood, Tom Parsons, and Mike McCurry for technical review of an earlier version of this paper, and Roger Stewart for a thorough and quite helpful editorial review. 


\section{REFERENCES CITED}

Amundson, Ronald, Oliver Chadwick, Carol Kendall, Yang Wang, and Michael DeNiro, 1996, Isotopic evidence for shifts in atmospheric circulation patterns during the late Quaternary in mid-North America: Geology, v. 24, p. 23-36.

Anders, M.H., 1994, Constraints on North American plate velocity from Yellowstone hotspot deformation field: Nature, v. 369, p. 53-55.

Anders, M.H., J.W. Geissman, L.A. Piety, and J.T. Sullivan, 1989, Parabolic distribution of circumeastern Snake River Plain seismicity and latest Quaternary faulting: Migratory pattern and association with the Yellowstone hot spot: Journal of Geophysical Research, v. 94. No. B2, p. 1,589-1,621.

Anderson, D.L., 1998, The edges of the mantle, in Michael Gurnis, M.E. Wysession, Elise Kittle, and B.A. Buffett, eds., The Core-Mantle Boundary Region, American Geophysical Union, Geodynamics Series, v. 28, p. 255-271.

Arthur, M.A., W.E. Dean, and S.O. Schlanger, 1985, Variations in the global carbon cycle during the Cretaceous related to climate, volcanism, and changes in atmospheric $\mathrm{CO}_{2}$, in E.T. Sundquist and W.H. Broecker, eds., The Carbon Cycle and Atmospheric $\mathrm{CO}_{2}$ : Natural Variations Archean to Present, American Geophysical Union Geophysical Monograph 32, p. 504-529.

Atwater, Tanya, 1989, Plate tectonic history of the northeast Pacific and western North America, in E.L. Winterer, D.M. Hussong, and R.W. Decker, eds., The Eastern Pacific Ocean and Hawaii: The Geology of North America, Geological Society of America, v. N, p. 21-72.

Baksi, A.K., 1989, Reevaluation of the timing and duration of extrusion of the Imnaha, Picture Gorge, and Grande Ronde Basalts, Columbia River Group, in S.P. Reidel, and P.R. Hooper, Volcanism and Tectonism in the Columbia River Flood Basalt Province: Geological Society of America Special Paper 239, p. 105-111.

Barnosky, A.D., and W.J. Labar, 1989, Mid-Miocene (Barstovian) environmental and tectonic setting near Yellowstone National Park, Wyoming and Montana: Geological Society of America Bulletin, v. 101, p. $1,448-1,456$.

Barron, J.A., and J.G. Baldauf, 1989, Tertiary cooling steps and paleoproductivity as reflected by diatoms and biosiliceous sediments, in Productivity of the Ocean: Present and Past, W.H. Berger, V.S. Smetacck, and G. Wefer, eds., John Wiley and Sons, . p. 341-354.

Barron, J.A., and Gerta Keller, 1982, Widespread Miocene deep-sea hiatuses: Coincidence with periods of global cooling: Geology, v. 10, p. 577-581.

Blackwell, D.D., 1989, Regional implications of heat flow of the Snake River Plain, northwestern United States: Tectonophysics, v. 164, p. 323-343.

Blakely, R.J., and R.C. Jachens, 1991, Regional study of mineral resources in Nevada: Insights from three-dimensional analysis of gravity and magnetic anomalies: Geological Society of America Bulletin, v. 103, p. 795-803.

Bonnichsen, Bill, 1982, The Bruneau-Jarbidge eruptive center, southwestern Idaho, in Bill Bonnichsen, and R.M. Breckenridge, eds., Cenozoic Geology of Idaho: Idaho Bureau of Mines and Geology Bulletin 26, p. 237-254.

Braile, L.W., W.J. Hinze, R.R.B. von Frese, and G.R. Keller, 1989, Seismic properties of the crust and uppermost mantle of the conterminous United States and adjacent Canada, in L.C. Pakiser, and W.D. Mooney, Geophysical Framework of the Continental United States: Geological Society of America Memoir 172, p. 655-680. 
Camp, V.E., 1995, Mid-Miocene propagation of the Yellowstone mantle plume head beneath the Columbia River basalt source region: Geology, v. 23, no. 5, p. 435-438.

Campbell, I.H., 1998, The mantle's chemical structure: Insights from melting products of mantle plumes, in Ian Jackson, ed., The Earth's Mantle: Cambridge University Press, Cambridge, p. 259-310.

Carlson, R.W., and W.K. Hart, 1987, Crustal genesis of the Oregon Plateau: Journal of Geophysical Research, v. 92, p. 6,191-6,206.

1988, Flood basalt volcanism in the northwestern United States, in J.D. Macdougall, ed., Continental Flood Basalts: Kluwer Academic Publishers, Dordrecht, The Netherlands, p. 35-61.

Christiansen, R.L., 1984, Yellowstone magmatic evolution: Its bearing on understanding large-volume explosive volcanism, in Explosive Volcanism: Inception, Evolution, and Hazards, Studies in Geophysics: National Academy Press, p. 84-95.

Christiansen, R.L., and E.H. McKee, 1978, Late Cenozoic volcanic and tectonic evolution of the Great Basin and Columbia intermontane regions, in R.B. Smith, and G.P. Eaton, eds., Cenozoic Tectonics and Regional Geophysics of the Western Cordillera: Geological Society of America Memoir 152, p. 283-311.

Christiansen, R.L, and R.S. Yeats, 1992, Post-Laramide geology of the U.S. Cordilleran region, in B.C. Burchfiel, P.W. Lipman, and M.L. Zoback, eds., The Cordilleran Orogen: Conterminous U.S.: The Geology of North America: Geological Society of America, v. G-3, p. 261-406.

Coffin, M.F., and Olav Eldholm, 1994, Large igneous provinces: Crustal structure, dimensions, and external consequences: Reviews of Geophysics, v. 32, p. 1-36.

Covington, H.R., 1983, Structural evolution of the Raft River basin, Idaho, in D.M. Miller, V.R. Todd, and K.A. Howard, eds., Tectonic and Stratigraphic Studies in the Eastern Great Basin: Geological Society of America Memoir 157, p. 229-237.

Crough, S.T., 1978, Thermal origin of mid-plate hot-spot swells: Geophysical Journal of the Royal Astronomical Society, v. 55, p. 451-469.

Davies, G.F., 1998, Plates, plumes, mantle convection, and mantle evolution, in Ian Jackson, ed., The Earth's Mantle: Cambridge University Press, Cambridge, p. 228-258.

Draper, D.S., 1991, Late Cenozoic bimodal magmatism in the northern Basin and Range Province of southeastern Oregon: Journal of Volcanology and Geothermal Research, v. 47, p. 299-328.

Drummond, C.N., B.H. Wilkinson, K.C. Lohmann, and G.R. Smith, 1993, Effect of regional topography and hydrology on the lacustrine isotopic record of Miocene paleoclimate in the Rocky Mountains: Palaeogeography, Palaeoclimatology, Palaeoecology, v. 101, p. 67-79.

Duncan, R.A., 1982, A captured island chain in the Coast Range of Oregon and Washington: Journal of Geophysical Research, v. 87, p. 10,827-10,837.

Duncan, R.A., and M.A. Richards, 1991, Hotspots, mantle plumes, flood basalts, and true polar wander: Reviews in Geophysics, v. 29, p. 31-50.

Elison, M.W., R.C. Speed, and R.W. Kistler, 1990, Geologic and isotopic constraints on the crustal structure of the northern Great Basin: Geological Society of America Bulletin, v. 102, p. 1,077-1,092.

Fields, R.W., D.L. Rasmussen, A.R. Tabrum, and R. Nichol, 1985, Cenozoic rocks of the intermontane basins of western Montana and eastern Idaho, in R.M. Flores and S.S. Kaplan, eds., Cenozoic Paleogeography of the West-Central United States: Society of Economic Paleontologists and Mineralogists, Rocky Mountain Section, p. 9-36. 
Friedman, Irving, Jim Glean, R.A. Shepherd, and A.J. Guide, III, 1993, Deuterium fractionation as water diffuses into silicic volcanic ash: Geophysical Monograph 78, p. 321-323.

Garnero, E.J., Justin Revenaugh, Quentin Williams, Thorne Lay, and L.H. Kellogg, 1998, Ultralow velocity zone at the core-mantle boundary in Michael Gurnis, M.E. Wysession, Elise Kittle, and B.A. Buffett, eds., the Core-mantle boundary region: American Geophysical Union, Geodynamics Series, v. 28, p. $319-334$

Geist, Dennis, and Mark Richards, 1993, Origin of the Columbia Plateau and Snake River Plain: Deflection of the Yellowstone plume: Geology, v. 21, p. 789-792.

Gregory, K.M., and C.G. Chase, 1992, Tectonic significance of paleobotanically estimated climate and altitude of the late Eocene erosion surface, Colorado: Geology, v. 20, p. 581-585.

Griffiths, R.W., and J.S. Turner, 1998, Understanding mantle dynamics through mathematical models and laboratory experiments, in Ian Jackson, ed., The Earth's Mantle: Cambridge University Press, Cambridge, p. 191-227.

Hill, D.P., 1972, Crustal and upper-mantle structure of the Columbia Plateau from long-range seismicrefraction measurements: Geological Society of America Bulletin, v. 83, p. 1639-1648.

Hill, R.I., I.H. Campbell, G.F. Davies, and R.W. Griffiths, 1992, Mantle plumes and continental tectonics: Science, v. 256, p. 186-193.

Hittleman, A.M., D.T. Dater, R.W. Buhmann, and S.D. Racey, 1994, Gravity-1994 edition (CD-ROM): National Geophysical Data Center, Boulder, CO (request flier SE-0703).

Hodell, D.A., and Fay Woodruff, 1994, Variations in the strontium isotopic ratio of seawater during the Miocene: Stratigrapic and geochemical implications: Paleoceanography, v. 9, p. 405-426.

Hooper, P.R., 1990, The timing of crustal extension and the eruption of continental flood basalts: Nature, v. 345 , p. $246-249$.

1997, The Columbia River flood basalt province: Current status, in J.J. Mahoney and M.F. Coffin, eds., Large Igneous Provinces: Continental, Oceanic, and Planetary Flood Volcanism: American Geophysical Monograph 100, p. 1-27.

Hooper, P.R., and C.J. Hawkesworth, 1993, Isotopic and geochemical constraints on the origin and evolution of the Columbia River basalt: Is there a $\mathrm{Ba} / \mathrm{La}$ ratio argument for the Vancouver slab?: Journal of Petrology, v. 34, p. 1,203-1,246.

House, M.A., B.P. Warnicke, and K.A., Farley, 1998, Dating topography of the Sierra Nevada, California, using apatite (U/Th)/He ages: Nature, v. 396, p. 66-69.

Jackson, Ian, and S.M. Rigden, 1998, Composition and temperature of the earth's mantle: Seismological models interpreted through experimental studies of earth materials, in Ian Jackson, ed., The Earth's Mantle: Cambridge University Press, Cambridge, p. 405- 460.

Johnston, S.T., P.J. Wynne, Don Francis, C.J.R. Hart, R.J. Enkin, and D.C. Engebretson, 1996, Yellowstone in Yukon: The late Cretaceous Carmaks Group: Geology, v. 24, p. 997-1,000.

Katzman, Rafael, Li Zhao, and T.H. Jordan, 1998, High-resolution, two dimensional vertical tomography of the central Pacific mantle using $S c S$ reverberations and frequency-dependent travel times: Journal of Geophysical Research, v. 103, p. 17,933-17,971.

Kistler, R.W., 1983, Isotope geochemistry of plutons in the northern Great Basin: Geothermal Resources Council, Davis, California, Special Report 13, p. 3-8. 
Kutzbach, J.E., P.J. Guetter, W.F. Ruddiman, and W.L. Prell, 1989, Sensitivity of climate to late Cenozoic uplift in southern Asia and the American West: Numerical experiments: Journal of Geophysical Research, v. 94, p. 18,393-18,407.

Lachenbruch, A.H., and J.H. Sass, 1978, Models of an extending lithosphere and heat flow in the Basin and Range province: Geological Society of America Memoir 152, p. 209-250.

Leavitt, S.W., 1982, Annual volcanic carbon dioxide emission: an estimate from eruption chronologies: Environmental Geology, v. 4, p. 15-21.

Leeman, W.P., 1982, Development of the Snake River Plain-Yellowstone Plateau province, Idaho and Wyoming: An overview and petrologic model, in Bill Bonnichsen, and R.M. Breckenridge, eds., Cenozoic Geology of Idaho: Idaho Bureau of Mines and Geology Bulletin 26, p. 155-178.

Leeman, W.P., J.S. Oldow, and W.K. Hart, 1992, Lithosphere-scale thrusting in the western U.S. Cordillera as constrained by $\mathrm{Sr}$ and $\mathrm{Nd}$ isotopic transitions in Neogene volcanic rocks: Geology, v. 20, p. 63-66.

Leopold, E.B., and M.F. Denton, 1987, Comparative age of grassland and steppe east and west of the northern Rocky Mountains: Annals of the Missouri Botanical Garden, v. 74, p. 841-867.

Leopold, E.B., and V.C. Wright, 1985, Pollen profiles of the Plio-Pleistocene transition in the Snake River Plain, Idaho: in Late Cenozoic History of the Pacific Northwest, American Association for the Advancement of Science, Pacific Division, San Francisco, p. 323-348.

Link, P.K., N. Christie-Blick, J.H. Stewart, J.M.G. Miller, W.J. Devlin, and M. Levy, 1993, Late Proterozoic strata of the United States Cordillera in P.K. Link and others, Middle and Late Proterozoic Stratified Rocks of the Western U.S. Cordillera, Colorado Plateau, and Basin and Range Province, in J.C. Reed, M.E. Bickford, R.S. Houston, P.K. Link, D.W. Rankin, P.K. Sims, and W.R. Van Schmus, eds., PreCambrian: Conterminous U.S.: Geological Society of America, The Geology of North America, Boulder, v. C-2, p. 536-558.

Lipman, P.W., 1992, Magmatism in the Cordilleran United States; Progress and problems: in B.C. Burchfiel, P.W. Lipman, and M.L. Zoback, eds., The Cordilleran Orogen: Conterminous U.S.: The Geology of North America: Geological Society of America, v. G-3, p. 481-514.

Love, J.D., L.A. Morgan, and W.C. McIntosh, 1997, The Teewinot Formation: Evidence for Late Miocene basin formation in response to volcanism, faulting, and uplift associated with the Yellowstone hotspot?: Geological Society of America Abstracts with Programs, v. 29, no. 6, p. A-365.

Luedke, R.G., and R.L. Smith, 1981, Map showing distribution and age of late Cenozoic volcanic centers in California and Nevada: U.S. Geological Survey Miscellaneous Geologic Investigations Map, I1091-C, scale 1:1,000,000.

1982, Map showing distribution and age of late Cenozoic volcanic centers in Oregon and Washington: U.S. Geological Survey Miscellaneous Geologic Investigations Map, I-1091-D, scale $1: 1,000,000$.

1983, Map showing distribution and age of late Cenozoic volcanic centers in Idaho, western Montana, west-central South Dakota, and northwestern Wyoming: U.S. Geological Survey Miscellaneous Geologic Investigations Map, I-1091-E, scale 1:1,000,000.

MacLeod, N.S., G.W. Walker, and E.H. McKee, 1976, Geothermal significance of eastward increase in age of upper Cenozoic rhyolitic domes in southeastern Oregon: Proceedings of the Second United Nations Symposium on the Development and Use of Geothermal Resources, v. 1, Washington, D.C., U.S. Government Printing Office, p. 456-474. 
Malde, H.E., 1991, Quaternary geology and structural history of the Snake River Plain, Idaho and Oregon, in R.B. Morrison, ed., Quaternary Nonglacial History of the Conterminous U.S.: Geological Society of America, The Geology of North America, v. K-2, ch. 4, p. 251-282.

McClean, D.M., 1985, Mantle degassing induced dead ocean in the Cretaceous-Tertiary transition, in E.T. Sundquist and W.H. Broecker, eds., The Carbon Cycle and Atmospheric $\mathrm{CO}_{2}$ : Natural Variations Archean to Present, American Geophysical Union Geophysical Monograph 32, p. 493-503.

Miller, K., and R.G. Fairbanks, and G.S. Mountain, 1987, Tertiary isotope synthesis, sea level history, and continental margin erosion: Paleooceanography, v. 2, p. 1-19.

Molnar, Peter, and Philip England, 1990a, Surface uplift, uplift of rocks, and exhumation of rocks: Geology, v. 18, p. 1,173-1,177.

Molnar, Peter, and Philip England, 1990b, Late Cenozoic uplift of mountain ranges and global climate change: Chicken or egg?: Nature, v. 346, p. 29-34.

Mooney, W.D., and L.W. Braile, 1989, The seismic structure of the continental crust and upper mantle of North America, in A.W. Bally, and A.R. Palmer, eds., The Geology of North America-An Overview: Geological Society of America, The Geology of North America, v. A, p. 39-52.

Mooney, W.D, and C.S. Weaver, 1989, Regional crustal structure and tectonics of the Pacific coastal states; California, Oregon, and Washington, in L.C. Pakiser, and W.D. Mooney, eds., Geophysical Framework of the Continental United States: Geological Society of America Memoir 172, p. 129161.

Morgan, J.P., W.J. Morgan, and Evelyn Price, 1995, Hotspot melting generates both hotspot volcanism and a hotspot swell?: Journal of Geophysical Research, v. 100, p. 8045-8062.

Morgan, L.A. and W.C. McIntosh, 2001, ${ }^{40} \mathrm{Ar} /{ }^{39} \mathrm{Ar}$ ages of silicic volcanic rocks in the Heise volcanic field, eastern Snake River Plain, Idaho: Timing of volcanism and tectonism, in Bill Bonnichsen, C.M. White, and Michael McCurry, eds., Tectonic and Magmatic Evolution of the Snake River Plain Volcanic Province: Idaho Geological Survey Bulletin.

Morgan, L.A., D.J. Doherty, and W.P. Leeman, 1984, Ignimbrites of the eastern Snake River Plain: Evidence for major caldera forming eruptions: Journal of Geophysical Research, v. 89, no. B10, p. $8,665-8,678$.

Morgan, L.A., W.C. McIntosh, and K.L. Pierce, 1997, Inferences for changes in plume dynamics from stratigraphic framework studies of ignimbrites, central Snake River Plain, Idaho: Geological Society of America Abstracts with Programs, v. 29, no. 6, p. A-299.

Morgan, Paul, and W.D. Gosnold, 1989, Heat flow and thermal regimes of the continental United States, in L.C. Pakiser, and W.D. Mooney, eds., Geophysical Framework of the Continental United States: Geological Society of America Memoir 172, p. 493-522.

Murphy, J.B., G.L. Oppliger, and G.H. Brimhall, Jr., 1998, Plume-modified orogeny: An example from the western United States: Geology, v. 26, p. 731-734.

Oppliger, G.L., J.B Murphy, and G.H. Brimhall, Jr., 1997, Is the ancestral Yellowstone hotspot responsible for the Tertiary Carlin mineralization in the Great Basin of Nevada?: Geology, v. 25, no. 7, p. 627-630.

Page, W.D., T.L. Sawyer, and P, R. Renne, 1995, Quaternary geology along the boundary between the Modoc Plateau, southern Cascades, and the northern Sierra; Friends of the Pleistocene, Pacific Cell Field Trip. 
Pakiser, L.C., 1989, Geophysics of the Intermontane system, in L.C. Pakiser, and W.D. Mooney, eds., Geophysical Framework of the Continental United States: Geological Society of America Memoir 172, p. 235-247.

Parsons, Tom, 1995, The Basin and Range Province, in K.H. Olsen, ed., Continental Rifts: Evolution, Structure, Tectonics, Developments: Geotectonics 25, Elsevier, Amsterdam, p. 277-324.

Parsons, Tom, G.A. Thompson, and N.H. Sleep, 1994, Mantle plume influence on the Neogene uplift and extension of the U.S. western Cordillera?: Geology, v. 22, p. 83-86.

Parsons, Tom, A.M. Trehu, J.H. Luetgert, Kate Miller, Fiona Kilbride, R.E. Wells, M.A. Fisher, Ernst Flueh, U.S. Ten Brink, and N.I. Christensen, 1998, A new view into the Cascade subduction zone and volcanic arc: Implications for earthquake hazards along the Washington margin: Geology, v. 26, p. 199-202.

Perkins, M.E., F.H. Brown, W.P. Nash, W. McIntosh, and S.K. Williams, 1998, Sequence, age, and source of silicic fallout tuffs in middle to late Miocene basins of the Basin and Range province: Geological Society of America Bulletin, v. 110, p. 344-360.

Pezzopane, S.K., and R.J. Weldon, II, 1993, Tectonic role of active faulting in central Oregon: Tectonics, v. 12 , p. 1,140-1,169.

Pierce, K.L., and L.A. Morgan, 1990, The track of the Yellowstone hot spot: Volcanism, faulting, and uplift: U.S. Geological Survey Open-File Report 90-415, 49 p.

1992, The track of the Yellowstone hot spot: Volcanism, faulting, and uplift, in P.K. Link, M.A. Kuntz, and L.B. Platt, eds., Regional Geology of Eastern Idaho and Western Wyoming: Geological Society of America Memoir 179, p. 1-53.

Pierce, K.L., D.G. Milbert, and R.W. Saltus, 1992, Geoid dome culminates on Yellowstone: Yellowstone hotspot fed by a thermal mantle plume?: EOS, Transactions of the American Geophysical Union, v. 73, p. 284.

Pyle, D.G., B.B. Hanan, D.W. Graham, and R.A. Duncan, 1997, Siletzia-Geochemistry and geochronology of Yellowstone hot spot volcanism in a suboceanic setting: Geological Society of America Abstracts with Programs, v. 29, no. 6, p. A-298.

Rasmussen, J., and E. Humphreys, 1988, Tomographic image of the Juan de Fuca plate beneath Washington and western Oregon using teleseismic P-wave travel times: Geophysical Research Letters, v. 15, p. $1,417-1,420$.

Rampino, M.R., 1991, Volcanism, climate change, and the geologic record, Society of Economic Paleontologists and Mineralogists, Special Publication 45, p.

Raymo, M.W., and W.F. Ruddiman, 1992, Tectonic forcing of late Cenozoic climate: Nature, v. 359, p. 117-122.

Raymo, M.W., W.F. Ruddiman, and P.N. Froelich, 1988, The influence of late Cenozoic mountain building on oceanic geochemical cycles, Geology, v. 16, p. 649-653.

Reed., J.C., Jr., 1993, Map of the PreCambrian rocks of the conterminous United States, in J.C. Reed, M.E. Bickford, R.S. Houston, P.K. Link, D.W. Rankin, P.K. Sims, and W.R. Van Schmus, eds., Precambrian: Conterminous U.S.: Geological Society of America, The Geology of North America, Boulder, v. C-2, Plate 1.

Reidel, S.P, N.P. Campbell, K.R. Fecht, and K.A. Lindwey, 1989, Late Cenozoic structure and stratigraphy of south central Washington, in Regional Geology of Washington State: Washington Department of Natural Resources Bulletin 80, p. 159-180. 
Richards, M.A., R.A. Duncan, and V.E. Courtillot, 1989, Flood basalts and hot spot tracks: Plume heads and tails: Science, v. 246, p. 103-107.

Rodgers, D.W., W.R. Hackett, and H.T. Ore, 1990, Extension of the Yellowstone Plateau, eastern Snake River Plain, and Owyhee Plateau: Geology, v. 18, p. 1,138-1,141.

Ruddiman, W.F., and J.E. Kutzbach, 1989, Forcing of late Cenozoic Northern Hemisphere climate by plateau uplift in southern Asia and the American West: Journal of Geophysical Research, v. 94, p. $18,409-18,427$.

Ruddiman, W.F., J.E. Kutzbach, and I.C. Prentice, 1997, Testing the climatic effects of orography and $\mathrm{CO}_{2}$ with general circulation and Biome models, in W.F. Ruddiman, ed., Tectonic Uplift and Climate Change, Plenum Press, New York, p. 204-235.

Ruddiman, W.F., W.L. Prell, and M.E. Raymo, 1989, Late Cenozoic uplift in southern Asia and the American West: Rationale for general circulation modeling experiments: Journal of Geophysical Research, v. 94, p. 18,379-18,391.

Ruddiman, W.F., M.E. Raymo, W.L. Prell, and J.E. Kutzbach., 1997, The uplift-climate connection: a synthesis, in W.F. Ruddiman, ed., Tectonic Uplift and Climate Change, Plenum Press, New York, p. 471-515.

Rytuba, J.J. and E.H. McKee, 1984, Peralkaline ash flow tuffs and calderas of the McDermitt volcanic field, southeast Oregon and north central Nevada: Journal of Geophysical Research, v. 89, no. B10, p. $8,616-8,628$.

Saltus, R.W., and G.A. Thompson, 1995, Why is it downhill from Tonopah to Las Vegas?: A case for a mantle plume support of the high northern Basin and Range: Tectonics, v. 14, p. 1,235-1,244.

Self, Stephen, Thorvaldur Thordarson, and Laszlo Keszthelyi, 1997, Emplacement of continental flood basalt lava flows, in J.J. Mahoney and M.F. Coffin, eds., Large Igneous Provinces: Continental, Oceanic, and Planetary Flood Volcanism: American Geophysical Monograph 100, p. 381-410.

Severinghaus, Jeff, and Tanya Atwater, 1990, Cenozoic geometry and thermal state of the subducting slabs beneath western North America, in B.P. Wernicke, ed., Basin and Range Extensional Tectonics Near the Latitude of Las Vegas, Nevada: Geological Society of America Memoir 176, p. 1-22.

Shervais, John, Scott Vetter, and Barry Hanan, 1997, Shaking the plume's tail: Basaltic volcanism in the central Snake River Plain, Idaho: Geological Society of America Abstracts with Programs, v. 29, no. 6, p. A-300.

Sleep, N.H., 1990, Hotspots and mantle plumes: Some phenomenology: Journal of Geophysical Research, v. 95 , no. B5, p. 6,715-6,736.

1997, Lateral flow and ponding of starting plume material: Journal of Geophysical Research, v. 102, no. B5, p. 10,001-10,012.

Smith, G.R., and W.P. Patterson, 1994, Mio-Pliocene seasonality on the Snake River Plain: Comparison of faunal and oxygen isotopic evidence: Palaeogeography, Palaeoclimatology, Palaeoecology, v. 107, p. 291-302.

Smith, R.B., and L.W. Braille, 1993, Topographic signature, space-time evolution, and physical properties of the Yellowstone-Snake River Plain volcanic system: The Yellowstone hotspot, in A.W. Snoke, J.R. Steidtmann, and S.M. Roberts, eds., Geology of Wyoming: Geological Survey of Wyoming Memoir No. 5, p. 694-754.

Snee, L.W., Karen Lund, J.F. Sutter, D.E. Balcer, and K.V. Evans, 1995, An ${ }^{40} \mathrm{Ar} /{ }^{39} \mathrm{Ar}$ chronicle of the 
tectonic development of the Salmon River suture zone, western Idaho, in T.L. Vallier and H.C. Brooks, eds., Geology of the Blue Mountains Region of Oregon, Idaho, and Washington: Petrology and Tectonic evolution of Pre-Tertiary Rocks of the Blue Mountain Region, U.S. Geological Survey Professional Paper 1438, p. 359-414.

Takahahshi, Eiichi, Katsuji Nakajima, and T.L. Wright, 1998, Origin of the Columbia River basalts; Melting model of a heterogeneous plume head: Earth and Planetary Science letters, v. 162 (1-4), pp. 63-80.

Taylor, D.W., and R.C. Bright, 1987, Drainage history of the Bonneville Basin, in Cenozoic Geology of Western Utah: Utah Geological Association Publication 16, p. 239-256.

Thelin, Gail, and R.J. Pike, 1991, Landforms of the conterminous United States-a digital shaded relief portrayal: U.S. Geological Survey Miscellaneous Geologic Investigations Map I-2206, scale $1: 3,500,000$.

Thompson, G.A., 1998, Deep mantle plumes and geoscience vision, Geological Society of America, and presidential address: GSA Today, April 1996, p. 17-25.

Thompson, G.A., R. Catchings, E. Goodwin, S. Holbrook, C. Jarchow, C. Mann, J. McCarthy, and D. Okaya, 1989, Geophysics of the western Basin and Range Province, in L.C. Pakiser, and W.D. Mooney, eds., Geophysical Framework of the Continental United States: Geological Society of America Memoir 172, p. 177-203.

Thompson, G.R., R.W. Fields, and David Alt, 1982, Land-based evidence for Tertiary climatic variations: Northern Rockies: Geology, v. 10, p. 413-417.

Thompson, R.N., and S.A. Gibson, 1991, Subcontinental mantle plumes, hotspots, and pre-existing thinspots: Journal of the Geological Society, London, v. 148, p. 973-977.

Vallier, T.L., 1995, Petrology of pre-Tertiary igneous rocks in the Blue Mountains province of Oregon, Idaho, and Washington: Implications for the geologic evolution of a complex island arc: U.S. Geological Survey Professional Paper 1438, p. 125-209.

Van der Lee, Susan, and Guust Nolet, 1997, Seismic image of the subducted trailing fragments of the Vancouver plate: Nature, v. 386, p. 266-269.

VanDecar, J.C., 1991, Upper-mantle structure of the Cascadia Subduction Zone from non-linear teleseismic travel-time inversion: University of Washington, Ph.D. dissertation.

Wagner, D.L., and G.J. Saucedo, 1990, Age and stratigraphic relationships of Miocene volcanic rocks along the eastern margin of the Sacramento Valley, California, in R.V. Ingersoll and T.H. Nilsen, eds., Sacramento Valley Symposium and Guidebook, Pacific Section S.E.P.M., v. 65, p. 143-151.

Walker, G.W., and Bruce Nolf, 1981, High lava plains, Brothers fault zone to Harvey Basin, Oregon, in D.A. Johnston, and Julie Donnelly-Nolan, eds., Guides to Some Volcanic Terranes in Washington, Idaho, Oregon, and Northern California: U.S. Geological Survey Circular 838, , p. 105-111.

White, R.S. and D.P. McKenzie, 1989, Magmatism at rift zones: The generation of volcanic continental margins and flood basalts: Journal of Geophysical Research, v. 94, no. B6, p. 7,685-7,729.

Wolfe, J.A., 1993, A method for obtaining climate parameters from leaf assemblages: U.S. Geological Survey Bulletin 2040, 71 p.

Wolfe, J.A., C.E. Forest, Peter Molnar, 1998, Paleobotanical evidence on Eocene and Oligocene paleoaltitudes in mid-latitude western North America: Geological Society of America Bulletin, v. 110 , p. 664-678. 
Wolfe, J.A., H.E. Schorn, C.E. Forest, and Peter Molnar, 1997, Paleobotanical evidence for high altitudes in Nevada during the Miocene: Science, v. 276, p. 1,672-1,675.

Wood, S.H., and Clemens, D.M., 2001, Geologic and tectonic history of the western Snake River Plain, Idaho and Oregon, in Bonnichsen, Bill, ed., Tectonic and Magmatic Evolution of the Snake River Plain Volcanic Province: Idaho Geological Survey Bulletin, v. 30.

Wright, J.D., and K.G. Miller, 1992, Miocene stable isotope stratigraphy, site 747, Kerguelen Plateau: Proceedings Ocean Drilling Program, Scientific Results, v. 120, p. 855-866.

Zoback, M.L., and G.A. Thompson, 1978, Basin and Range rifting in northern Nevada: Clues from a midMiocene rift and its subsequent offsets: Geology, v. 6, p. 111-116.

Zoback, M.L., R.E. Anderson, and G.A. Thompson, 1981, Cainozoic evolution of the state of stress and style of tectonism of the Basin and Range Province of the western United States: Philosophical Transactions of the Royal Society of London, v. A 300, p. 407-434.

Zoback, M.L., E.H. McKee, R.J. Blakely, and G.A. Thompson, 1994, The northern Nevada rift: Regional tectono-magmatic relations and middle Miocene stress direction: Geological Society of America Bulletin, v. 106, p. 371-382. 


\section{Table Captions}

Table 1. A sampling of possible indicators of uplift, altitude, and precipitation shadow that may be related to Yellowstone hotspot plume uplift.

\section{Figure Captions}

Figure 1. Map of western United States showing the track of the Yellowstone hotspot (after Pierce and Morgan, 1992, fig. 23). The 10- to-2-Ma track is compatible with plate motion, whereas the 10- to 16-Ma track has apparent rates three times faster than predicted. Projecting back from $10 \mathrm{Ma}$, we infer the plume was located at the site of the hexagon. As shown by the arrowed line, the geologic location of the inferred plume head was about $260 \mathrm{~km}$ further west at about the McDermitt caldera. Assuming the Vancouver slab was in the subsurface (figs. 2 and 3), buoyant rise up the slab may have deflected the plume head westward the $260 \mathrm{~km}$ shown by the arrowed line. Strontium lines after Reed (1993) with modifications in Washington from Robert Fleck (written commun., 1998) and southeastern Idaho from Leeman and others (1992). Transect A-A' is portrayed in Figure 5.

Figure 2. Location of the Yellowstone plume relative to the North American Plate and the Vancouver slab (or Juan de Fuca slab; from Severinghaus and Atwater, 1990). The plume is assumed to be fixed in the mantle and now 50-km northeast of the 2.0-Ma caldera that started the Yellowstone Plateau volcanic field. Hotspot migration of $29 \mathrm{~km} / \mathrm{m}$.y. from 2 to $10 \mathrm{Ma}$ is plotted as a circled star on the line of section. This rate of $29 \mathrm{~km} / \mathrm{m}$.y. is close to the plate motion rate of $22 \pm 8 \mathrm{~km} / \mathrm{m} . \mathrm{y}$. and includes tectonic extension that probably accounts for the apparent difference of $7 \mathrm{~km} / \mathrm{m}$.y. Cross sections are drawn to go through the McDermitt caldera and are nearly parallel to plate motion and to the inclination of the Vancouver slab. The reconstruction of Severinghaus and Atwater (1990) accounts for deformation, and the numbers on the Vancouver slab indicate the thermal state of the slab with 1 meaning solid enough to have earthquakes and 10 meaning nearly the same as the surrounding mantle.

Figure 3. Postulated westward deflection of the Yellowstone plume head by buoyant rise up the inclined Vancouver slab. Time sequence from $30 \mathrm{Ma}$ (top) to present (bottom) with position of plume held fixed in the mantle. At $20 \mathrm{Ma}$, the plume head has intersected the inclined Vancouver slab and is being displaced westward, and by $16 \mathrm{Ma}$ the plume center is beneath McDermitt (along the OR/NV rift), about $260 \mathrm{~km}$ west of its feeding plume tail. As the plume flattens, the area of the plume in this cross section diminishes to about half because of spreading in the third dimension. The inclination of the Vancouver slab is shown to increase from $30 \mathrm{Ma}$ to present (see text under heading "Reconciliation Based..."). Numbers on slab (1, 3, 5, and 10) are the thermal state of slab from Severinghaus and Atwater (1990); see also Figure 2. This cartoon does not account for interaction with the 660and 410-km discontinuities.

Figure 4. Some positions for the Yellowstone hotspot at different times as postulated by others and by us. The location between 50 and $17 \mathrm{Ma}$ presents a problem that is avoided if the Yellowstone plume starts at $17 \mathrm{Ma}$.

Figure 5. Geological and geophysical characteristics along section A-A' (see fig. 1). From McDermitt, this section goes south, parallel to the Nevada-Oregon rift zone and north parallel to the feeder dikes of the 
Columbia River and Oregon Plateau basalts. The Strontium isotopic boundaries $\left({ }^{87} \mathrm{Sr}{ }^{86} \mathrm{Sr}\right)$ define crustal changes with Precambrian silicic continental crust inside (continent-ward) the 706 line and Mesozoic and younger mafic oceanic crust outside (oceanward) the 704 line $\left({ }^{87} \mathrm{Sr} /{ }^{86} \mathrm{Sr} 0.704\right.$ and 0.706 shown here as 704 and 706).

A. 14-17-Ma magmatism near and along the Nevada-Oregon rift zone, which is about 1,100-km long (from fig. 1). The rhyolite overlaps both the southern part of the flood basalts and the mafic, rift-filling dikes of the Northern Nevada rift. The 14-17-Ma rhyolites fade out roughly in the area where 21-37-Ma magmatism had already occurred, perhaps related to crustal depletion.

B. Crustal ages and origin. Strontium boundaries from Reed (1993, Plate 1, except where updated in Washington by Robert Fleck, written commun., 1998, and in southwest Idaho by Leeman and others, 1992). Precambrian areas from Link and others (1993, fig. 34 and p. 552-557). Northern Nevada from divisions by Elison and others (1990). Oregon after Draper (1991, p. 315) suggesting 2-4 km volcanic and volcaniclastic rock over 15-20 km of oceanic crustal material. Carlson and Hart (1987, fig. 8) show this area as new crust over depleted upper mantle.

C. Heat flow (in $\mathrm{mWm}^{-2}$ ) from Morgan and Gosnold (1989).

D. Regional topography from averaging of five parallel profiles spaced $15 \mathrm{~km}$ apart and centered on section A-A'.

E. Regional complete Bouguer gravity anomaly from averaging of five parallel profiles spaced 15 $\mathrm{km}$ apart and centered on section A-A'. The data are from the Decade of North American Geology (DNAG) data compilation for the conterminous United States (available on CD-ROM from National Geophysical Data Center, Boulder, Colorado; Hittelman and others, 1994). Thin line shows fit to model shown in $\mathrm{F}$ (below).

F. Gravity model of lithosphere and upper asthenosphere. Crust/mantle boundary taken from an average of several Moho maps (Mooney and Weaver, 1989; Pakiser, 1989; Braile and others, 1989). Southern boundary of "hot asthenosphere" taken from Saltus and Thompson (1995). Northern boundary of "hot asthenosphere" interpreted here to coincide with the gravity/topographic step centered at about $-380 \mathrm{~km}$ on A-A'. The boundary between the upper (felsic) and lower (mafic) crust was allowed to vary between sea level and the Moho to match the Bouguer anomalies. This simple model shows that the gravity data are consistent with a crust that is largely mafic to the north and felsic to the south.

Figure 6. Geologic cartoon along line of section A-A' showing emplacement of postulated Yellowstone plume head. The plume head spreads out (pancakes, mushrooms) upon rising into the lithosphere, but it can rise further beneath the thinner lithosphere (young thin mafic crust and lithospheric mantle) beneath Oregon. Decompression melting (squiggly vertical lines) produces basalt magma that rises upward and interacts differently with the crust: (A) in Oregon, magma rises through the dense, more oceanic crust, and surfaces as the Columbia River and Oregon Plateau flood basalts, and (B) in Nevada and southern Oregon, basalt magma melts silicic lower crustal material that then rises into upper crust forming magma chambers (oval pods) and rhyolitic ignimbrite eruptions, shown as volcanoes, and (C) in northernmost Nevada and southern Oregon, both processes have operated. The restite from decompression melting remains in the mantle but is buoyant and contributes to longlasting uplift (Morgan and others, 1995). At the time of emplacement, doming above the plume head may be $1-2 \mathrm{~km}$ (exaggerated in drawing). The northward gravitational push from this doming may have produced the Yakima fold belt near the northern end of the section. 
Figure 7. Age progression of silicic lava domes of the southern Oregon rhyolite belt. This figure shows upper Miocene and younger volcanic rocks and is copied from Christiansen and Yeats (1992, fig. 55). The rhyolite domes and their ages were shown by MacLeod and others (1976) to have such a systematic northwest decrease in age that ages could be contoured in one-million-year increments. This northwest age progression is a key argument against a plume origin for the Yellowstone hotspot (Lipman, 1992; Christiansen and Yeats, 1992). See Figure 9 for our suggestions about how the southern Oregon rhyolite belt might be reconciled with a thermal plume origin of the Yellowstone hotspot. Both the southern Oregon rhyolite belt and the Yellowstone hotspot track start in the region near McDermitt, but they become younger in nearly opposite directions at the same time. The silicic domes (dark) form two belts that trend N. $75^{\circ} \mathrm{W}$. The northern belt ends at Newberry caldera and parallels the Brothers fault zone (wide gray line) which is actually a complex en echelon pattern of normal faults whose trend of about $10^{\circ}$ clockwise to the overall pattern (Walker and Nolf, 1981) suggests a right lateral component (Pezzopane and Weldon, 1993). Between 10 and 17 Ma, ignimbrites and other silicic volcanism are widespread in the southern Oregon, northern Nevada and southwestern Oregon area (fig. 1; Pierce and Morgan, 1992;) but have no systematic progression with age in southeast Oregon (MacLeod and others, 1976, p. 470).

Figure 8. Geologic sketch (after Draper, 1991) along the southern Oregon rhyolite belt parallel to the trend of the Brothers fault zone. The mounds numbered 10 to 1 represent contours on the age or rhyolitic volcanism in Ma (MacLeod and others, 1976). Following Draper (1991), we suggest several factors may have acted separately or in combination to produce penetration of mantle lithosphere by basaltic melts to form rhyolite magma from crust: (1) cracking of mantle lithosphere by westward migration of activity on Brothers fault zone, (2) westward spreading of plume head, and (3) thermal erosion of mantle lithosphere associated with counterflow. Fracturing of the lithosphere along the Brothers fault zone (MacLeod and others, 1976; Carlson and Hart, 1987; Pezzopane and Weldon, 1993) appears to have provided the conduits for volcanism as well as its overall northwest trend. The most reasonable mechanism for the northwest progression of rhyolitic volcanism may be a northwest progression of faulting to form the Brothers fault zone. Such a northwest progression of faulting might have been accompanied by a northwestward migration of plume head material aided by both general outward migration of the plume head, and by counter flow between the Vancouver slab and North American plate (Draper, 1991). If the two proceeded together, the faulting may have caused fracturing of the mantle lithosphere permitting the erosion and stooping of the mantle lithosphere (a mechanism suggested by George Thompson, oral commun., 1998) and thus forming an inverted channel enhancing both outward (northwestward) plume head flow and decompression melting by thinning of the lithosphere. Although Draper (1991) drew a similar diagram, we include this version because many have argued that this northwestward volcanic progression negates the Yellowstone hotspot as a mantle plume, and we think these factors offer a mantle-plume compatible explanation. The geometry of the subducting slab is based on a fairly well controlled section by Parsons and others (1998) near the Oregon-Washington border.

Figure 9. Uplift and climatic patterns that may relate to Yellowstone plume (both head and tail). The dashed line shows the pancaked plume with a diameter suggested by Parsons and others (1994) of about $400 \mathrm{~km}$ but elongated north south as suggested by Camp (1995) parallel to the Nevada-Oregon rift zone. Table 1 describes the various localities, areas, and transects shown here. One of the main climatic parameters listed is orographic dryness (light shading) in the lee of the inferred Yellowstone plume-head uplift. In general, observations of uplift and climate are compatible with uplift above the plume head followed by uplift migrating to the east associated with the plume tail (chimney) to the 
"Yellowstone crescent of high terrain" associated with the present plume tail (Pierce and Morgan, 1992) or a similar 650-m-high altitude anomaly that Smith and Braille (1993) associated with the current Yellowstone hotspot.

Figure 10. Temporal relations among Cenozoic climate proxies, "large igneous provinces" (flood basalts) and postulated Yellowstone plume-head uplift. Atlantic deep waters (after Miller and others, 1987, as shown in Barron and Baldauf, 1989). The about 14- to 17-Ma middle Miocene "climatic optimum" (expanded plot, right side from Barron and Keller, 1982) has been associated with the Columbia River-Oregon Plateau flood basalts (CRB, for example, Hodell and Woodruff, 1994). After the Miocene "climatic optimum," cooling continued eventually to the Pliocene-Pleistocene ice ages. Uplift associated with the Yellowstone plume head is a candidate for a "plateau uplift" whose plumehead mechanism could produce significant late Cenozoic uplift (fig. 9). Global climatic modeling by Kutzbach and others (1989) and Ruddiman and others, (1997) shows that "plateau uplifts" could produce late Cenozoic climatic cooling in the Northern Hemisphere that might lead to the PlioPleistocene ice ages. Late Cenozoic Yellowstone plume uplift (head and tail) could also diminish atmospheric $\mathrm{CO}_{2}$ leading to cooling, by the mechanism of Raymo and Ruddiman (1992) and Ruddiman and others (1997). Plume-head uplift does not have the geophysical problem of a plausible mechanism of how the isostatic balance of the lithosphere could rapidly change that Molnar and England (1990a; b) used to challenge the validity of late Cenozoic "plateau uplifts". 